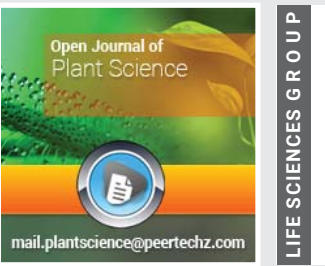

\section{Heterosis and character}

\section{association of mid altitude}

\section{adapted quality protein maize}

\section{(Zea mays L.) hybrids at Bako,} Western Ethiopia

\section{Beyene Abebe ${ }^{1 *}$, Wassu Mohammed Ali ${ }^{2}$ and Adefris Teklewold Chere $^{3}$}

${ }^{1}$ Ethiopian Institute of Agricultural Research (EIAR), Bako National Maize Research Center, Bako, Ethiopia

${ }^{2}$ International Maize and Wheat improvement Center (CIMMYT) Ethiopia office, Addis Ababa, Ethiopia

${ }^{3}$ Haramaya University, college of Agriculture and Environmental Sciences, Dere Dawa, Ethiopia
Received: 29 January, 2020

Accepted: 30 April, 2020

Published: 01 May, 2020

*Corresponding author: Beyene Abebe, Ethiopian Institute of Agricultural Research (EIAR), Bako National Maize Research Center, Bako, Ethiopia,

E-mail: beyene78@gmail.com

Keywords: Better parent; Direct effect; Genotypic correlation; Indirect effect; Mid parent; Phenotypic correlation

https://www.peertechz.com

Check for updates

\begin{abstract}
The production of hybrid Quality Protein Maize (QPM) is started very recently in Ethiopia that requires extensive research to exploit heterosis to increase the productivity of the crop. Exploitation of heterosis through the production of hybrids is proven breeding method to improve the yield of maize. Accordingly, the aims of this study were to estimate the magnitude of heterosis of QPM inbred lines and to determine the association among morph-agronomic traits. The crossing and experiment were conducted at Bako National Maize Research Center during the 2014 and 2015 main cropping season, respectively. Forty-five $F_{1}$ hybrids obtained by crossing 10 inbred lines in diallel fashion were planted in two separate trials on adjacent experimental blocks. The experimental design used was alpha lattice for the hybrid trial and randomized complete block design for inbred lines trial with three replications. Each entry was planted on a one-row plot of $5.1 \mathrm{~m}$ length with $0.75 \mathrm{~m}$ and $0.3 \mathrm{~m}$ spacing between rows and plants, respectively for both trials. Data on phenology, growth, grain yield and yield related traits, and disease reaction were collected at the appropriate plant growth stages. The mean squares due to hybrids and parents were highly significant for all traits except common leaf rust in the hybrids trial and diseases parameters, stem lodging, bad husk cover and ear rot indicating the existence of genetic variability for most traits. The highest positive mid and better parents heterosis was observed for grain yield and yield related traits indicating the possibility of increasing grain yield and yield related characters via hybridization. Negative heterosis was observed for phenology and growth traits and diseases parameters as well. Grain yield had highly significant positive association with plant height, ear plant ${ }^{-1}$, ear length and number of kernel row $^{-1}$ and negatively correlated with anthesis silk interval, plant and ear aspect, common lea rust, phaeosphaeria leaf spot and ear rot at genotypic and phenotypic level. In addition, plant height, ear plant ${ }^{-1}$, ear length, number of kernel row had positive direct effects and anthesis silk interval, plant aspect, phaeosphaeria leaf spot and ear rot had negative direct effects on grain yield at both genotypic and phenotypic level; while, common leaf rust had negative direct effects at genotypic and days to anthesis, ear height, root lodging and ear aspect had negative direct effects on grain yield at phenotypic level. This indicated that, by increasing the positive and decreasing the negative direct effects of the traits grain yield could increase invariably.
\end{abstract}

\section{Introduction}

Maize (Zea mays L.) is the basic staple cereal grain and currently produced on above two million hectares and the $2^{\text {nd }}$ most widely grown crop in Ethiopia and stands first in terms of production ( 9.5 million ton) and productivity 4 ton per ha. It is produced by about nine million farmers indicating its popularity and importance to the livelihoods of more than $70 \%$ of the farming households in Ethiopia [1].

The conventional maize grown widely around the world supplies many macros and micronutrients necessary for human metabolic needs; however, it lacks B vitamins and the essential amino acids lysine and tryptophan [2-4]. Consequently, 
population heavily dependent on maize run the risk of incurring retarded growth and health problem associated with protein deficiency if maize protein is not complemented in the diet by other protein sources which are high in these amino acids, such as meat, legumes and dairy products $[5,6]$.

Improving the quality of maize protein for human consumption by increasing its lysine and tryptophan through decreasing the zeins protein fraction content has therefore been a long-term goal of several maize breeding programs [7, 8]. The bio-fortification of conventional maize by doubling the amount of lysine and tryptophan through the identification of a mutant genotype, popularly known as opaque-2 (02), with reduced zeins protein fraction and improved agronomic performance gave rise to newly commercialized maize types called Quality Protein Maize (QPM) [9].

In most maize hybrid breeding programs, the main objective is to develop improved inbred lines that can form best hybrids upon crossing [10]. Sustainable production of QPM in Ethiopia and elsewhere is dependent not only on its nutrition benefit but also on how much can be harvested per unit area of land. Unless the productivity of QPM is comparable or better than the conventional maize varieties currently in use, farmers may be reluctant to produce it. This requires a rigorous inbred line development and evaluation work to identify potential parental lines for hybrid variety development.

The concept of heterosis is practically exploited to develop hybrid varieties. Heterosis may be defined as the increase in size, vigor, fertility, and overall productivity of a hybrid plant, over the mid parent value (average performance of the two parents) and over the performance of best parent. It is occurred when two inbred lines of out bred species are crossed, as much as when crosses are made between pure lines [11].

Although yield is usually the primary trait of interest, maturity, stand-ability, grain quality, stem quality, and resistance to major diseases and insects are all corollary traits that the maize breeder must consider for eventual usefulness of genotypes evaluated for yield [12].

Correlation is the degree to which two or more variables are related and change together [13]. Usually more than one trait is measured on progenies evaluated either for a specific trait in cyclical selection programs or in applied breeding programs that require a combination of traits to satisfy growers. In genetics, there are two main causes of correlation between characters, genetic and environmental. The genetic cause of correlation is chiefly pleiotropy, though linkage is a cause of transient correlation, particularly in population derived from crosses between divergent strains [14]. It has established in classical genetics that many genes have manifold effects; i.e., some genes seem to affect traits that are unrelated. Genes that have manifold effects are pleiotropic, i.e., the same gene affects different traits in a complementary way. The existence of pleiotropic effects of genes in different classical genetic studies showed the presence of pleiotropy in different quantitatively inherited traits. Then it is possible that selection may be exerted on secondary traits that have greater heritability than the primary trait. Indirect selection will be effective if the heritability of the secondary trait is greater than that of the primary trait and the genetic correlation between them is substantial [12]. In maize, both genetic and environmental correlations have been extensively studied by various researchers and their importance with respect to a particular trait has been well documented $[15,16]$.

Correlation coefficients do not give a complete picture of the causal basis of association and selection based on correlation coefficients without taking into consideration the interaction between the component traits could be misleading. Therefore, to design appropriate breeding strategies for improvement in yield through selection, it would be desirable to conduct both correlation and path coefficient analysis [17]. Path coefficient can be defined as a ratio of the standard deviation of the effect due to a given cause to the total standard deviation of the effect [18].

Therefore, this study is initiated to support the quest for better mid-altitude adapted QPM hybrid varieties in Ethiopia with the following specific objectives: to estimate the magnitude of heterosis in crosses derived from mid altitude QPM inbred and the association of traits with grain yield.

\section{Materials and methods}

\section{Description of experimental site}

The experiment was conducted at Bako National Maize Research Center (BNMRC), which is located in Western Ethiopia. Bako Maize Research Center lies between $9^{\circ} 6^{\prime}$ North latitude and $37^{\circ} 09^{\prime}$ east longitude at an altitude of 1650 meters above sea level (m.a.s.l.) in the sub-humid agroecology of Ethiopia.

\section{Experimental materials}

Ten white-grained Quality Protein Maize (QPM) inbred lines obtained from BNMRC were crossed using diallel mating design during the main cropping season of 2014 and forty-five single cross hybrids were generated. The parental inbred lines were selected based on their tryptophan and lysine content and per se performance history for grain yield and yield related traits. The inbred lines which contain good level of essential amino acids, lysine ( $4 \%$ in whole grain) and tryptophan ( $>0.8 \%$ in whole grain) were selected [19]. The parental inbred lines and the resulting hybrids (45) were organized into two separate sets of trials and tested in adjacent blocks (hybrids and inbred lines trials) at Bako trials evaluating site to avoid the unbalanced competition between the hybrids and inbred lines.

\section{Experimental design}

The $45 \mathrm{~F}_{1}$ hybrids and the 10 inbred lines were planted following experimental design $9 \times 5$ alpha-lattice (0.1) for the hybrid trial Patterson and Williams, [19] and a randomized complete block design (RCBD) for the inbred line trial each with three replications. Each entry (the hybrids and parental inbred lines) was planted in a one-row plot of $5.1 \mathrm{~m}$ length and $0.75 \mathrm{~m}$ between rows and $0.3 \mathrm{~m}$ distance between plants in a row.

Citation: Abebe B, Ali WM, Chere AT (2020) Heterosis and character association of mid altitude adapted quality protein maize (Zea mays L.) hybrids at Bako, Western 


\section{Data collected}

Phenology and growth data: 1 . Days to anthesis (AD): The number of days from planting to when $50 \%$ of the plants in a plot shed pollen. 2. Days to silking (SD): The number of days from planting to when $50 \%$ of the plants in a plot $2-3 \mathrm{~cm}$ long silk. 3. Anthesis Silking Interval (ASI): Recorded as the number of days between days to silking and days to anthesis (ASI= SD - AD). 4. Ear Height (EH): The height from the ground level to the base of the upper most ear-bearing node of five randomly taken plants from each experimental unit was measured in centimetres. The measurement was made two weeks after pollen shedding has ceased.5. Plant Height ( $\mathrm{PH})$ : The height from the soil surface to the base of the first tassel branch of five randomly taken plants from each experimental unit was measured in centimetres. Like ear height, this was also measured two weeks after pollen shedding had ceased from the same plants that were used to measured ear height.

Grain yield and yield related traits data; 1 . Grain yields (GY), at harvesting ears were removed from all plants in each plot leaving other crop residues (husk, leaf, stem and tassel) intact. The total field weight from all the ears of each experimental unit was measured. This was adjusted to $12.5 \%$ moisture (electronically determined using digital moisture tester) level and $80 \%$ shelling percentage to estimate grain yield in tons ( $\mathrm{t} \mathrm{ha}^{-1}$ ) for each genotype. 2. Root Lodging (RL): Prior to harvest, the number of plants inclined more than $30^{\circ}$ from the vertical axis were counted and recorded. The data was calculated as (number of root lodged plants)/ (total plants per plot) $\times 100$ ]. 3. Number of Ears Per Plant (EPP): The total number of ears harvested from a plot divided by the number of plants in that particular plot at harvest. 4. Ear Length (EL): Length of the ear from the base to tip. It has been measured as the average length of five randomly taken ears from each experimental unit in centimeter. 5. Ear Diameter (ED): This was measured at the mid-way along ear length, as the average diameter of five randomly taken ears from each experimental plot in centimeter. 6. Number of kernel rows per ears (NKR): This was recorded as the average number of kernel rows per ears from the five randomly taken ears. 7. Number of Kernels per Row (NKPR): This was recorded as the average number of kernels per row from 10 randomly taken ears. 8 Plant Aspect (PA): Recorded using 1-5 scale; where, 1 is best genotype (considering the overall performance of the plant in the field) and 5 is the genotypes have undesirable overall plant appearance. 9. Ear Aspect (EA): Record using 1-5 scale; where, 1 refers to good ears (considering the overall appearance of the ear) and 5 refers to poor ear with undesirable ear characteristics. 10. Number of Rotten Ears (ER): counting and recording the number of ears rotten from the total number of harvested ears per plot. Reaction of the genotypes to Turcicum Leaf Blights (TLB) and Phaeosphaeria Leaf Spot (PLS) were evaluated. The disease severity scores were rated as 1-5 rating scale was used where, 1 is the best and 5 the worst in terms of reaction to the diseases. In addition, the intermediate ratings between two numerals $(1.5,2.0,2.5,3.0,3.5,4.0$ and 4.5) have also been used for all the diseases under study.

\section{Data analysis}

Mid Parent Heterosis (MPH) and Better Parent Heterosis $(\mathrm{BPH})$ in percent were calculated for those parameters that showed significant differences among $\mathrm{F}_{1}$ hybrids and parental lines following the method suggested by [14]. The estimate of mid and better parent heterosis, was done only when both parents and crosses had showed significance difference for the respective traits.

$$
\begin{aligned}
& \text { MPH (\%) }=\frac{F 1-M P}{S E(d)} \\
& \text { BPH (\%) }=\frac{(F 1-B P)}{B P} \times 100 \\
& \text { SH (\%) }=\frac{(F 1-S V)}{S V} \times 100
\end{aligned}
$$

Where, $\mathrm{F}_{1}=$ Mean value of the cross

MP = Mean value of the two parents

$\mathrm{BP}=$ Mean value of the better parent

$$
\mathrm{SV}=\text { Mean value of standard variety }
$$

Significance of heterosis has been tested using the t-test against the critical difference (CD).The $\mathrm{CD}$ for testing the significance of mid parent (MP) and better parent (BP) was calculated as suggested by $[20,21]$, Cochran and Cox [20] and Singh and Chaudhary [21] as follows:

Critical difference (CD) for heterosis over MP:

$$
\text { CD for MP }= \pm(\sqrt{3 e M S / 2 r}) \times t
$$

$$
\begin{aligned}
& \mathrm{SE}(\mathrm{d}) \text { for } \mathrm{MP}= \pm(\sqrt{2 e M S / r}) \\
& \mathrm{t}(\text { mid- parent })=R=\sqrt{1-\sum p_{i j} r_{i j}}
\end{aligned}
$$

2. Critical difference for heterosis over better parent.

$$
\begin{aligned}
& \mathrm{CD} \text { for } \mathrm{BP}= \pm(\sqrt{2 e M S / r}) \times t \\
& \mathrm{SE}(d) \text { for } \mathrm{BP}= \pm(\sqrt{2 e M S / r}) \\
& \mathrm{t} \text { (better parent) }=\frac{F 1-B P}{S E(d)} \text { and }
\end{aligned}
$$

Where, SE (d) is standard error of the difference, eMS is the error mean square is the number of replication and $\mathrm{F}_{1}, \mathrm{MP}$ and $\mathrm{BP}$ are mean values of the hybrids, mid-parent and better parent respectively. The computed $t$ values have been tested against the $t$ value at the error degrees of freedom for table value at $5 \%$ and $1 \%$ probability levels.

\section{Association of characters}

Genotypic and phenotypic correlation coefficients were calculated according to Al-Jibouri, et al. [22], from the analysis of variance and covariance as follow:

$$
\text { Genotypicr }=\frac{\sigma_{g 12}}{\sqrt{\left(\sigma_{g 1}^{2}\right)\left(\sigma_{g 1}^{2}\right)}}
$$




$$
\text { Phenotypicr }=\frac{\sigma_{p 12}}{\sqrt{\left(\sigma_{p 1}^{2}\right)\left(\sigma_{p 2}^{2}\right)}}
$$

where $\sigma_{\mathrm{p} 12}$ is the phenotypic covariance between the two traits, $\sigma_{p 1}^{2}$ is the phenotypic variance of the first trait and $\sigma_{p 2}^{2}$ is phenotypic variance of the second triat, $\sigma_{g 12}^{2}$ is the genotypic covariance between the two traits, $\sigma_{q 1}^{2}$ is the genotypic variance of the first trait and $\sigma_{q 2}^{2}$ is the genotypic variance of the second traits

The phenotypic correlation coefficients were tested for traits of significance with ' $r$ ' table for sample correlation coefficients at n-2 degree of freedom, as suggested by [13] while the genotypic correlation coefficients were tested for their significance using the formula.

$$
\begin{aligned}
& t=\frac{r_{g x y}}{S E_{g x y}} \\
& S E_{g x y}=\sqrt{\frac{\left(1-r^{2}\right)^{2}}{2 h^{2} h_{x}^{2} y}}
\end{aligned}
$$

The ' $t$ ' value, calculated using the above formula, was compared with ' $\mathrm{t}$ ' tabulated at $(\mathrm{g}-2)$ degree of freedom at $1 \%$ and $5 \%$ levels of significance; where, $r_{g x y}$ is the genotypic correlation between $\mathrm{x}$ and $\mathrm{y}$ traits; $\mathrm{g}=$ number of genotypes, $\mathrm{h}_{\mathrm{x}}^{2}$ and $\mathrm{h}_{\mathrm{y}}^{2}$ are heritability for traits $\mathrm{x}$ and $\mathrm{y}$, respectively.

\section{Path coefficient}

A path coefficient analysis was computed according to [17].
A path coefficient analysis is simply a standardized partial regression coefficient. The general formula used was:

$$
r_{i j}=p_{i j}+\sum r_{i k} p_{k j}
$$

Where, $r i j=$ mutual association between the independent character (i) and dependent character ( $j$ ) as measured by the correlation coefficients; $\mathrm{p}_{\mathrm{ij}}=$ components of direct effects of the independent character ( $\mathrm{j}$ ) as measured by the path-coefficients, and $\sum \mathrm{r}_{\mathrm{ik}} \mathrm{p}_{\mathrm{kj}}=$ summation of the components of indirect effects of a given independent character (i) via all other independent characters $(\mathrm{k})$.

The residual effect was computed as:

$$
R=\sqrt{1-\sum p_{i j} r_{i j}}
$$

Where, $R$ is residual, $p_{i j}$ is direct effect, and $r_{i j}$ is the correlation coefficients.

\section{Results and discussions}

\section{Analysis of variances}

Analysis of variance conducted for both hybrid and inbred lines trials showed the existence of significant differences among genotypes for all traits Table 1 below.

The significant genotypic mean squares observed for most traits in both sets of trials indicated the existence of appreciable level of differences in the performances of hybrids and inbred

\begin{tabular}{|c|c|c|c|c|c|c|}
\hline \multicolumn{5}{|c|}{ Hybrids } & \multicolumn{2}{|c|}{ Inbred lines } \\
\hline Trait & $\begin{array}{l}\text { Hybrids } \\
(D f=44)\end{array}$ & $\begin{array}{c}\text { Replication } \\
\quad(D f=2)\end{array}$ & $\begin{array}{c}\text { Blocks } \\
(D f=18)\end{array}$ & $\begin{array}{c}\text { Error } \\
(D f=78)\end{array}$ & $\begin{array}{l}\text { Lines } \\
(D f=9)\end{array}$ & $\begin{array}{c}\text { Error } \\
(D f=18)\end{array}$ \\
\hline GY & 3.0 ** & 4.41 & 0.97 & 0.64 & $7.31^{\star \star}$ & 0.09 \\
\hline EL & $3.49 * \star$ & 36.6 & 1.24 & 0.92 & $15.0^{\star *}$ & 1.17 \\
\hline ED & 0.31 ** & 32.7 & 0.03 & 0.03 & $0.49 * \star$ & 0.02 \\
\hline EA & $0.35^{\star \star}$ & 0.1 & 0.23 & 0.09 & $0.96^{\star \star}$ & 0.09 \\
\hline NKR & $3.5^{\star \star}$ & 8.63 & 0.81 & 0.59 & $2.56^{\star \star}$ & 0.63 \\
\hline NKPR & $10.3^{* \star}$ & 366.7 & 9.76 & 6.05 & $77.1^{\star \star *}$ & 6.11 \\
\hline$A D$ & $34.0^{* \star}$ & 1.23 & 3.27 & 1.63 & $77.7^{\star \star *}$ & 1.49 \\
\hline ASI & $8.7^{\star \star}$ & 0.21 & 0.43 & 1.16 & $22.8^{\star \star}$ & 2.19 \\
\hline $\mathrm{PH}$ & 262.0 ** & 604.6 & 245.1 & 141.7 & $2225.9 \star \star$ & 63.04 \\
\hline $\mathrm{EH}$ & $697.1^{* *}$ & 202.3 & 106.4 & 96.7 & $593.8^{\star \star}$ & 82.9 \\
\hline NEPP & $0.19 * \star$ & 0.05 & 0.05 & 0.03 & $0.40^{\star \star}$ & 0.04 \\
\hline PA & $0.31^{* \star}$ & 0.03 & 0.18 & 0.14 & $0.73^{\star \star}$ & 0.12 \\
\hline $\mathrm{RL}$ & $260.5^{\star \star}$ & 377.4 & 149.9 & 146.3 & $4264.2^{\star \star}$ & 136.9 \\
\hline ER & $218.9 * \star$ & 53.7 & 41.3 & 50 & 293.6 & 136.8 \\
\hline TLB & $0.23^{\star \star}$ & 0.47 & 0.13 & 0.13 & 0.70 & 0.11 \\
\hline PLS & $0.31^{\star \star}$ & 0.05 & 0.14 & 0.16 & $0.41^{\star \star}$ & 0.11 \\
\hline
\end{tabular}
lines for those traits. This indicates the possibility of making selection for further improvement of both sets of genotypes.

Table 1: Analysis of variances for phenology and growth, grain yield and yield related traits and diseases parameters for maize hybrids and inbred lines evaluated at Bako, Ethiopia in 2015 cropping season.

** and * significant at probability level of $\mathrm{P}<0.01$ and $\mathrm{P}<0.05$, respectively; Df: Degrees of freedom; GY: Grain yield, EL: Ear Length, ED: Ear Diameter; EA: Ear Aspect: NKP: Number of Kernels Row; NKPR: Number of Kernels Per Rows; AD: days to anthesis; ASI: Anthesis Silking Interval; PH: Plant height; EH: Ear Height; EPP: Number of Ears Per Plant; PA: Plant Aspect; RL: Root Lodging; ER: Ear Rot; TLB: Turcicum Leaf Blight; PLS: Pheasphorial Leaf Spot and Values with no asterisk are non-significant.

Citation: Abebe B, Ali WM, Chere AT (2020) Heterosis and character association of mid altitude adapted quality protein maize (Zea mays L.) hybrids at Bako, Western Ethiopia. Open J Plant Sci 5(1): 013-025. DOI: https://dx.doi.org/10.17352/ojps.000018 
The non-significant differences observed among the parental inbred lines for TLB, PLS and ER might attribute to the fact that the selected inbred lines were relatively resistant to these diseases as a result of prior selection as compared with the hybrids.

Similar to the current study, other author has reported the existence of significant differences among hybrids and inbred lines Habtamu, et al. [23]. This is because the selection of inbred lines for higher performances and for different traits to exploit hybrid vigor/heterosis in the crosses made among them.

\section{Heterosis estimates}

For $\mathrm{GY}$, all $\mathrm{F}_{1}$ hybrids showed positive and highly $(\mathrm{P}<0.01)$ significant mid and better parent heterosis except cross L5 $\times$ L2, L8 $\times$ L7 and L9 $\times$ L5 crosses were showed significant $(\mathrm{P}<0.05)$ better parent heterosis, and $\mathrm{L} 5 \times \mathrm{L} 3$ that revealed nonsignificant $(\mathrm{P}>0.05)$ better parent heterosis. Mid and better parent heterosis for GY ranged from $16.51(\mathrm{~L} 5 \times \mathrm{L} 3)$ to $473.07 \%$ $(\mathrm{L} 4 \times \mathrm{L} 2)$ and $38.02(\mathrm{~L} 5 \times \mathrm{L} 3)$ to $507.71 \%(\mathrm{~L} 4 \times \mathrm{L} 2)$, respectively. In both cases, $\mathrm{L} 4 \times \mathrm{L} 2$ consistently manifested the highest percentage heterosis. In previous studies, several authors found significant and positive mid and better parent heterosis for GY in different maize genotypes Ojo, et al. [24], AbdelMoneam, et al. [25] and Dagne, et al, [26].

Most $\mathrm{F}_{1}$ crosses evaluated in the current study had negative mid and better parent heterosis for number of ears per plant (EPP). Mid-parent heterosis ranged from $-34.2(\mathrm{~L} 6 \times \mathrm{L} 5)$ to $55.9 \%(\mathrm{~L} 8 \times \mathrm{L} 3)$, whereas better parent heterosis ranged from $-49.9(\mathrm{~L} 6 \times \mathrm{L} 5)$ to $33.5 \%(\mathrm{~L} 8 \times \mathrm{L} 3)$. Out of $45 \mathrm{~F}_{1}$ hybrids, only five hybrids showed significant and positive mid parent heterosis, which is desirable as it indicates the prolificacy of the $\mathrm{F}$ progenies as compared to the parental lines up on hybridization. On the other hand, negative heterosis indicates that parents bear a greater number of EPP than their $F_{1}$ progenies. This result agrees with the findings of Bello and Olawuyi [27], who observed only six crosses with significant and positive heterosis for number of EPP out of 28 crosses evaluated. The present result is contrasting with the findings of Dagne, et al. [26], who reported higher number of $F_{1}$ hybrids with positive mid and better parent heterosis but few hybrids with negative mid and better parent heterosis among the hybrids of 15 QPM inbred lines.

Mid-parent heterosis value for ear length (EL) and ear diameter (ED) ranged from $13.12(\mathrm{~L} 8 \times \mathrm{L} 5)$ to $62.64 \%(\mathrm{~L} 7 \times \mathrm{L} 2)$ and from $7.49(\mathrm{~L} 8 \times \mathrm{L} 5)$ to $46.08 \%(\mathrm{~L} 4 \times \mathrm{L} 2)$, respectively, indicating that all $\mathrm{F}_{1}$ crosses showed highly significant and positive mid parent heterosis for these traits. Better parent heterosis for both EL and ED varied between $0.54(\mathrm{~L} 10 \times \mathrm{L} 8)$ to $62.24 \%(\mathrm{~L} 7 \times \mathrm{L} 2)$ and $1.73(\mathrm{~L} 8 \times \mathrm{L} 6)$ to $36.37 \%(\mathrm{~L} 4 \times \mathrm{L} 2)$, respectively. About 80 percent of the $\mathrm{F}_{1}$ crosses revealed significant and positive better parent heterosis for EL, while, about $88 \%$ of the $\mathrm{F}_{1}$ hybrids showed significant and positive better parent heterosis for ED. In line with the present findings, Berhanu [28], reported positive and significant mid and better parent heterosis for ED in most $\mathrm{F}_{1}$ hybrids studied. Habtamu, et al. [23], reported positive and significant mid parent and better parent heterosis ranging from positive to negative for EL. Among $80 \mathrm{~F}_{1}$ crosses evaluated, Gudeta [29], reported that more than $61 \%$ of the crosses had positive and significant heterosis over the better parent while more than $98 \%$ of the crosses showed positive and significant heterosis over the mid parent for EL. He also reported that most of the $\mathrm{F}_{1}$ crosses had positive and significant better parent and mid parent heterosis. The heterosis observed for EL and ED could be exploited in mid-altitude quality protein maize breeding program to develop desirable genotypes.

All the $\mathrm{F}_{1}$ crosses showed highly significant $(\mathrm{P}<0.01)$ and positive mid and better parent heterosis for number of kernels row $^{-1}$ (NKPR). Mid parent heterosis were ranged from $12.39 \%$ $(\mathrm{L} 8 \times \mathrm{L} 7)$ to $66.4 \%(\mathrm{~L} 9 \times \mathrm{L} 1)$, whereas better parent heterosis ranged from $1.08 \%(\mathrm{~L} 7 \times \mathrm{L} 5)$ to $28.26 \%(\mathrm{~L} 9 \times \mathrm{L} 1)$. The results of present study corroborate with the findings of Jehan, et al. [30], who observed high heterosis for NKPR in diallel crosses of maize inbred lines. Bayisa, et al. [31], also reported that $98 \%$ of the crosses they evaluated showed positive mid parent heterosis while, $65 \%$ of the same crosses had positive better parent heterosis for this trait. In contrast to the current study, Habtamu, et al. [23], reported low mid and better parent heterosis values for late maturity group of Maize inbred lines.

The disparity among the results of these studies might be attributed to the differences in the type and maturity group of the materials used.

For Number of Kernel Rows (NKR), only 10 and $3 F_{1}$ hybrids had significant and positive mid and better parent heterosis, respectively. Mid-parent heterosis for the trait ranged from $-7.84(\mathrm{~L} 7 \times \mathrm{L} 5)$ to13.99 \% (L6 $\times \mathrm{L} 3)$ while better parent heterosis varied from $-10.19(\mathrm{~L} 7 \times \mathrm{L} 5)$ to $8.23 \%(\mathrm{~L} 6 \times \mathrm{L} 1)$. Both positive and negative percent heterosis observed for NKR, indicates that the $F_{1}$ hybrids had either higher or lower number of rows than their respective parents. Similar results were previously reported Dagne, et al. [32].

Values of mid and better parent heterosis for all traits are presented in Table 2. With respect to days to Anthesis (AD), almost all crosses had highly $(\mathrm{P}<0.01)$ significant and negative mid and better parent heterosis, except L10 $\times \mathrm{L} 5$ for mid-parent and other four crosses for better parent showed non-significant heterosis. The negative heterosis indicated earlier flowering of the $F_{1}$ crosses as compared to the mean performance of the inbred parents i.e., hybrids take a smaller number of days to flowering than the inbred lines. The current results agree with the findings of other researchers who conducted similar studies on different inbred lines in different countries Iqbal, et al. [33] and Bello and Olawuyi [27].

All $\mathrm{F}_{1}$ hybrids had highly significant and positive mid and better parent heterosis for Ear Height (EH) and Plant Height (PH). Mid parent heterosis for $\mathrm{EH}$ and $\mathrm{PH}$ ranged from 36 to $115 \%$ and 25.67 to $95.19 \%$, respectively. While a better parent heterosis varied between 22.79 to $97.47 \%$ and 13.48 to $74.89 \%$ for $\mathrm{EH}$ and $\mathrm{PH}$ in that order. The positive and significant heterosis observed for $\mathrm{PH}$ confirms the increase in hybrid vigor up on hybridization as previously reported by Berhanu [28].

Citation: Abebe B, Ali WM, Chere AT (2020) Heterosis and character association of mid altitude adapted quality protein maize (Zea mays L.) hybrids at Bako, Western 
Table 2: Mid and batter parent heterosis for grain yield and yield related traits in QPM hybrids evaluated at Bako during the 2015 main season.

\begin{tabular}{|c|c|c|c|c|c|c|c|c|c|c|}
\hline Cross & \multicolumn{5}{|c|}{ Mid parent heterosis } & \multicolumn{5}{|c|}{ Better parent heterosis } \\
\hline Code & GY & EPP & EL & ED & NKR & GY & $\mathrm{EL}$ & EPP & ED & NKR \\
\hline L2 x L1 & $218.3^{\star \star}$ & -13.3 & $49.9 * \star$ & $30.0 * \star$ & $11.6^{\star \star}$ & $136.6^{\star \star}$ & $44.3^{\star \star}$ & -22.5 & $26.3^{\star \star}$ & 7.42 \\
\hline L3 x L1 & $183.2^{\star \star}$ & $18.5^{\star}$ & $56.4^{\star \star}$ & $24.0^{\star \star}$ & 0.0 & $144.1^{\star \star}$ & $51.4^{\star \star}$ & 10.9 & $16.1^{\star \star}$ & 0.0 \\
\hline L3 x L2 & $237.2^{\star \star}$ & -9.26 & $53.6 * \star$ & $38.7^{\star \star}$ & 2.78 & $128.1^{\star \star}$ & $43.3^{* \star}$ & $-23.4^{\star}$ & 33.4 *夫 & 1.83 \\
\hline L4 x L1 & $381.3^{\star \star}$ & $21.8^{*}$ & $51.3^{* *}$ & $32.4^{\star \star}$ & 4.19 & $272.8^{\star *}$ & $42.5^{\star \star}$ & 13.8 & $20.5^{\star \star}$ & 2.75 \\
\hline L4 x L2 & 507.7 *夫 & 13.6 & $56.0^{\star \star *}$ & $46.1^{\star \star}$ & 3.46 & $473.1^{\star \star}$ & $41.3^{\star \star}$ & 8.24 & 36.4 *夫 & 2.28 \\
\hline L4 x L3 & $136.8^{* \star}$ & 14.5 & $26.7^{\star \star}$ & $18.4^{\star \star}$ & -0.82 & $65.5^{\star \star}$ & $22.6 * \star$ & 0.67 & $14.8^{\star *}$ & -1.09 \\
\hline L5 x L1 & $118.7^{\star \star}$ & $-16.5^{\star}$ & $34.3^{\star *}$ & $22.4^{\star \star}$ & 3.5 & $63.8^{* \star}$ & $20.1^{\star \star}$ & $-32.2^{\star \star}$ & $20.7^{\star \star}$ & 2.3 \\
\hline L5 x L2 & $97.2^{\star \star}$ & $-28.8^{\star \star}$ & $28.0^{\star \star *}$ & $20.3^{\star \star}$ & $8.84^{*}$ & $22.5^{\star}$ & $10.6^{*}$ & $-46.9 \star \star$ & $18.7^{\star \star}$ & 5.73 \\
\hline L5 x L3 & $38.0 * \star$ & $-18.9 *$ & $18.9 \star \star$ & 17.6 ** & 4.02 & 16.5 & 9.49 & $-30.4^{\star \star}$ & $11.5^{\star \star \star}$ & 2.65 \\
\hline L5 x L4 & 123.0 ** & -9.64 & $30.0^{\star \star}$ & $21.3^{\star \star}$ & 4.07 & $42.0^{\star \star \star}$ & $23.4^{\star \star}$ & $-30.2^{\star \star}$ & $11.8^{\star \star}$ & 2.67 \\
\hline L6 x L1 & 146.0 ** & -14.6 & $42.3^{\star \star}$ & $23.2^{\star \star}$ & $12.9^{\star \star}$ & $107.2^{\star \star \star}$ & $41.5^{\star \star}$ & -21.7 & 12.6 *夫 & $8.23 *$ \\
\hline L6 x L2 & $152.3^{* \star}$ & -9.46 & $32.4^{\star *}$ & $25.9 * \star$ & $12.8^{\star \star \star}$ & $68.2^{\star \star}$ & 28.0 ** & -12 & $12.2^{\star \star}$ & $8.15^{\star}$ \\
\hline L6 x L3 & $125.2^{\star \star}$ & -13.2 & $42.2^{\star \star}$ & $20.2^{\star \star}$ & $14.0^{\star \star \star}$ & $119.1^{\text {** }}$ & 37.0 ** & $-25.0 *$ & 3.43 & 8.91 \\
\hline L6 x L4 & 175.0 ** & -3.6 & 35.0 ** & $23.8^{\star \star *}$ & $12.6^{\star \star}$ & $89.2^{\star \star}$ & 26.0 ** & -5.6 & 3.83 & 8.08 \\
\hline L6 x L5 & $52.4^{\star \star}$ & $-34.2^{\star \star}$ & $25.8^{\star \star *}$ & $22.3^{\star *}$ & 0.0 & $31.7 * \star$ & $11.9 *$ & $-49.9 \star \star$ & $10.3^{\star \star *}$ & 0.0 \\
\hline L7 x L1 & $174.2^{\star \star}$ & -15.9 & $61.2^{\star \star}$ & $24.7 \star \star$ & -1.78 & 171.0 ** & $55.5^{\star \star}$ & $-26.3^{\star}$ & $21.5^{\star \star}$ & -2.36 \\
\hline L7 x L2 & $323.4^{\star \star}$ & 14.0 & 62.6 ** & $30.8^{* \star}$ & 0.7 & $212.3^{\star \star}$ & $62.2^{\star \star}$ & 11.4 & 24.0 ** & 0.46 \\
\hline L7 x L3 & $145.7^{\star \star *}$ & -2.96 & $49.9 * \star$ & $21.4^{\star \star}$ & 4.81 & 113.9 ** & $40.2^{\star \star}$ & -19.6 & $10.8^{\star \star}$ & 3.16 \\
\hline L7 x L4 & $266.8^{\star \star}$ & $27.1^{\star}$ & $49.2^{\star \star}$ & $21.2^{\star \star}$ & 4.87 & $181.8^{\star \star}$ & $35.4^{\star \star}$ & 18.5 & $7.65^{\star}$ & 3.19 \\
\hline L7 x L5 & $82.1^{\star *}$ & -13.0 & $30.3^{\star \star}$ & $14.4^{\star \star}$ & -7.84 & $37.5^{\star \star}$ & $12.8^{*}$ & $-36.0 * \star$ & $9.92^{\star \star}$ & $-10.2^{*}$ \\
\hline L7 x L6 & $144.9 * \star$ & 4.83 & $42.6^{\star *}$ & $17.2^{\star \star}$ & -6.15 & $108.3^{\star \star}$ & $38.2^{\star \star}$ & $38.2^{\star \star}$ & $9.68^{* \star}$ & -8.04 \\
\hline L8 x L1 & 83.0 ** & -12.1 & $18.5^{\star \star}$ & $13.4^{\star \star}$ & -3.58 & $41.6^{\star \star}$ & -2.53 & -2.53 & $12.4^{\star \star}$ & -4.72 \\
\hline L8 x L2 & $112.0^{\star \star}$ & 3.99 & $23.9 \star \star$ & $23.6^{* \star}$ & $11.5^{\star \star}$ & $34.2^{\star \star}$ & -1.08 & -1.08 & $21.3^{\star \star}$ & 7.36 \\
\hline L8 x L3 & $98.4^{\star \star}$ & $55.9 * \star$ & 26.6 ** & $15.2^{\star \star}$ & $8.71 *$ & $74.1^{\star \star}$ & 6.87 & 6.87 & $8.81^{\star}$ & 5.64 \\
\hline L8 x L4 & 144.8 ** & 8.05 & $27.7^{\star \star}$ & $22.7^{\star \star \star}$ & 7.24 & $59.2^{\star \star}$ & $10.9 *$ & $10.9 *$ & $12.6^{\star \star}$ & 4.71 \\
\hline L8 x L5 & $40.3^{\star \star}$ & $-27.8^{\star \star}$ & $13.1^{\star \star}$ & $7.49 *$ & -1.4 & $34.0^{\star \star}$ & 2.89 & 2.89 & 6.98 & -1.85 \\
\hline L8 x L6 & $85.0^{\star \star *}$ & -1.09 & $23.8^{\star \star}$ & $12.3^{\star \star}$ & 2.0 & $66.4^{\star \star}$ & 1.45 & 1.45 & 1.73 & 1.32 \\
\hline L8 x L7 & $63.2^{\star \star}$ & -7.99 & $17.1^{\star \star *}$ & $9.2^{\star \star}$ & -4.39 & $27.3^{*}$ & -6.33 & -6.33 & 5.41 & -5.77 \\
\hline L9 x L1 & $200 . * *$ & -4.34 & $46.1^{\star \star}$ & $27.5^{\star \star}$ & $8.92^{\star}$ & $175.8^{\star \star}$ & $35.3^{\star \star}$ & $35.3^{\star \star}$ & $25.0^{\star \star}$ & 5.78 \\
\hline L9 x L2 & $242.2^{\star \star}$ & 17.57 & $44.7^{\star *}$ & $27.8^{\star \star}$ & 2.78 & $140.7^{* *}$ & $29.4^{\star \star}$ & $29.4^{\star \star}$ & $26.6^{\star \star}$ & 1.83 \\
\hline L9 x L3 & $144.0^{\star \star \star}$ & -3.6 & 44.0 ** & $20.3^{\star *}$ & 7.16 & 127.7 ** & $37.5^{\star \star}$ & $37.5^{\star \star}$ & $14.7^{\star \star *}$ & 4.66 \\
\hline L9 x L4 & $225.2^{\star \star}$ & 23.9 & $50.9 * \star$ & $23.6^{\star \star}$ & 1.64 & $137.2^{\star \star}$ & $48.7^{\star \star \star}$ & $48.7^{\star \star}$ & $14.4^{\star \star}$ & 1.09 \\
\hline L9 x L5 & $56.0^{\star \star}$ & $-19.0 *$ & $22.5^{\star \star}$ & $20.7 \star \star$ & -1.4 & $24.5^{\star}$ & $17.9 \star \star$ & $17.9^{\star \star \star}$ & $20.1^{\star \star}$ & -1.85 \\
\hline L9 x L6 & $112.3^{\star \star}$ & -12 & 39.9 ** & $23.3^{\star \star *}$ & 5.26 & $93.1^{\star \star *}$ & $28.9 \star \star$ & $28.9 \star \star$ & $10.7^{\star \star \star}$ & 3.45 \\
\hline L9 x L7 & $150.2^{\star \star \star}$ & 2.86 & $45.2^{\star \star}$ & $18.9 * \star$ & 0.72 & $132.2^{\star \star}$ & $30.1^{\star \star}$ & $30.1^{\star \star}$ & $13.7^{\star \star \star}$ & 0.48 \\
\hline L9 x L8 & $94.9 * *$ & 2.9 & $27.4^{\star \star}$ & $13.8^{\star \star *}$ & 5.94 & $61.2^{\star \star}$ & $11.9^{\star \star}$ & $11.9 * \star$ & $12.7^{\star \star}$ & 3.88 \\
\hline Cross & \multicolumn{6}{|c|}{ Mid parent heterosis } & \multicolumn{4}{|c|}{ Better parent heterosis } \\
\hline Code & GY & EPP & $\mathrm{EL}$ & ED & NKR & GY & EPP & $\mathrm{EL}$ & ED & NKR \\
\hline $\mathrm{L} 10 \times$ L 1 & $156.5^{\star \star}$ & 14.0 & $35.7 \star \star$ & $25.3^{\star \star}$ & 0.71 & $107.3^{\star \star}$ & 0.59 & $28.6^{\star \star}$ & $20.9^{\star \star}$ & 0.47 \\
\hline L10 x L2 & $154.2^{\star \star}$ & -0.37 & $41.0^{\star \star}$ & $34.7^{\star \star}$ & $9.50 *$ & $65.2^{\star \star}$ & $-20.2^{\star}$ & $28.8^{\star \star}$ & $33.6^{\star *}$ & 6.14 \\
\hline L10 x L3 & $117.3^{\star \star}$ & -0.94 & $41.0^{\star \star}$ & $32.4 \star \star$ & $11.0^{*}$ & $101.1^{\star \star}$ & -7.0 & $37.8^{\star \star}$ & $28.3^{\star \star}$ & 7.07 \\
\hline L10 x L4 & $196.0 * \star$ & $34.4^{\star \star}$ & $38.2^{\star \star}$ & $23.1^{\star \star}$ & 4.87 & $98.1^{\star \star}$ & 11.9 & $36.9 \star \star$ & $15.8^{\star \star *}$ & 3.19 \\
\hline L10 x L5 & $63.3^{\star \star}$ & -11.1 & $16.9 \star \star$ & $21.9 \star \star$ & -1.4 & $47.6^{\star \star}$ & $-19.2^{\star \star}$ & 9.93 & $19.3^{\star \star}$ & -1.85 \\
\hline L10 x L6 & $113.1^{\star \star}$ & -15.2 & $36.2^{\star \star}$ & $23.7^{\star \star}$ & 3.96 & $102.5^{\star \star}$ & $-30.5^{\star \star}$ & $28.3^{\star \star}$ & $9.44^{\star \star}$ & 2.61 \\
\hline L10 x L7 & $149.7 \star \star *$ & 17.5 & $45.1^{\star \star}$ & $18.6^{\star \star}$ & 0.0 & $103.7^{\star \star \star}$ & -7.43 & $32.8^{\star \star}$ & $11.5^{\star \star}$ & 0.0 \\
\hline L10 x L8 & $91.1^{\star \star}$ & 9.64 & $16.8^{\star \star}$ & $16.5^{\star \star *}$ & $12.4^{\star *}$ & $80.3^{* *}$ & -11.0 & 0.54 & $13.4^{\star \star}$ & 7.91 \\
\hline L10 x L9 & $108.7^{\star \star}$ & -4.68 & 38.87 ** & $29.1 \star \star$ & 2.78 & $81.3^{\star \star}$ & $-24.3^{\star \star}$ & $35.6^{\star \star}$ & $26.9 * \star$ & 1.83 \\
\hline Minimum & 38 & -34.2 & 13.1 & 7.49 & -7.8 & 16.5 & -49.9 & 0.54 & 1.73 & -10.2 \\
\hline Maximum & 507.7 & 55.9 & 62.6 & 46.1 & 14 & 473.1 & 33.5 & 62.2 & 36.4 & 8.23 \\
\hline$C D a_{0.05}$ & 0.47 & 0.1 & 0.55 & 0.1 & 1.1 & 0.77 & 0.17 & 0.91 & 0.17 & 0.73 \\
\hline $\mathrm{CD} \mathrm{a}$ & 0.63 & 0.14 & 0.73 & 0.13 & 1.45 & 1.02 & 0.23 & 1.19 & 0.22 & 0.97 \\
\hline
\end{tabular}

** and * significant at probability level of $\mathrm{P}<0.01$ and $\mathrm{P}<0.05$, respectively; $\mathrm{D} f=$ Degrees of freedom, $\mathrm{CD}=\mathrm{critical}$ difference, $\mathrm{GY}=\mathrm{Grain}$ yield, $\mathrm{EPP}=$ number of ears per plants, $\mathrm{EL}=$ ear length, $\mathrm{ED}=$ ear diameter, $\mathrm{NKP}=$ number of kernels row, and Values with no asterisk are non-significant.

Citation: Abebe B, Ali WM, Chere AT (2020) Heterosis and character association of mid altitude adapted quality protein maize (Zea mays L.) hybrids at Bako, Western Ethiopia. Open J Plant Sci 5(1): 013-025. DOI: https://dx.doi.org/10.17352/ojps.000018 
Table 2: Continued.

\begin{tabular}{|c|c|c|c|c|c|c|c|c|}
\hline \multirow{2}{*}{$\begin{array}{l}\text { Cross } \\
\text { Code }\end{array}$} & \multicolumn{4}{|c|}{ Mid parent heterosis } & \multicolumn{4}{|c|}{ Better parent heterosis } \\
\hline & $A D$ & $\mathrm{EH}$ & $\mathrm{PH}$ & NKPR & $A D$ & $\mathrm{EH}$ & $\mathrm{PH}$ & NKPR \\
\hline L2 x L1 & $-10.3^{\star \star}$ & $62.0 \star \star$ & $62.5^{\star \star}$ & $55.9 \star \star$ & $-3.62^{\star}$ & $52.5^{\star \star}$ & $38.7^{\star \star \star}$ & $24.5^{\star \star}$ \\
\hline L3 x L1 & $-9.20 * \star$ & 80.0 ** & $66.0 \star \star$ & $50.8^{\star \star}$ & -9.06 ** & $73.2^{\star \star}$ & $50.5^{\star \star}$ & $27.7 \star \star$ \\
\hline L3 x L2 & $-12.2^{\star \star}$ & $72.0^{\star \star \star}$ & $82.7^{\star \star \star}$ & $31.5^{\star \star}$ & $-5.43^{\star \star}$ & $56.4^{\star \star}$ & $70.7^{\star \star}$ & $18.3^{\star \star *}$ \\
\hline L4 x L1 & $-11.5^{\star \star}$ & 101.0 ** & $75.4^{\star \star}$ & $61.7 \star \star$ & $-9.06 * \star$ & $95.4 \star \star$ & $69.1 * \star$ & $26.8^{* *}$ \\
\hline$\llcorner 4 \times$ L2 & $-14.5^{\star \star}$ & 115.0 ** & $95.2^{\star \star}$ & $50.5^{\star \star}$ & $-5.43^{\star \star}$ & $97.5^{\star \star}$ & $71.9 \star \star$ & 20.8 ** \\
\hline L4 x L3 & $-8.60^{\star \star}$ & 85.0 ** & $73.4^{\star \star *}$ & $21.3^{\star \star}$ & $-6.27^{\star \star}$ & $83.4^{\star \star}$ & $62.6^{\star \star}$ & $5.8 * \star$ \\
\hline L5 x L1 & $-9.84^{\star \star}$ & $50.0^{\star \star *}$ & $36.5^{\star \star}$ & $35.2^{\star \star}$ & $-5.98 \star \star$ & 33.0 ** & $24.3^{\star \star}$ & $26.4^{\star \star}$ \\
\hline L5 x L2 & $-9.45^{\star \star}$ & $49.0^{\star \star}$ & $47.8^{\star \star}$ & $14.0 *$ & $-6.79 \star \star$ & $26.3^{\star \star}$ & $16.9 \star \star$ & $15.2^{\star \star}$ \\
\hline L5 x L3 & $-9.20 * \star$ & $49.0 \star \star$ & $43.9 * \star$ & $13.8^{* \star}$ & $-5.13^{\star \star}$ & $37.0^{\star \star}$ & $20.0^{\star \star}$ & 10.0 ** \\
\hline L5 x L4 & $-8.77^{\star \star}$ & $73.0^{\star \star *}$ & $51.6^{\star \star}$ & $22.6^{\star \star}$ & -2.14 & $58.2^{\star \star}$ & $33.6^{\star \star}$ & 18.0 ** \\
\hline L6 x L1 & $-10.6^{\star \star}$ & $64.0^{\star \star \star}$ & $50.2^{\star \star}$ & $52.8^{\star \star}$ & $-3.64^{\star}$ & 58.0 ** & $43.5^{\star \star}$ & 25.0 ** \\
\hline L6 x L2 & $-13.8^{\star \star}$ & 45.0 ** & $60.7^{\star \star \star}$ & $29.1^{\star \star}$ & $-13.6^{\star \star}$ & $41.5^{\star \star}$ & $42.7^{\star \star}$ & $14.1^{* *}$ \\
\hline L6 x L3 & $-14.1^{\star \star}$ & $68.0^{\star \star \star}$ & $69.2^{\star \star}$ & $35.3^{\star \star}$ & $-7.27 \star \star$ & $56.3^{\star \star}$ & $60.1^{\star \star}$ & 11.9 ** \\
\hline L6 x L4 & $-14.3^{\star \star}$ & $84.0^{\star \star}$ & $54.4^{\star \star}$ & 36.0 ** & $-5.00 * \star$ & $72.9 * \star$ & $52.9 \star \star$ & 16.0 ** \\
\hline L6 x L5 & $-7.93^{\star \star}$ & $43.0^{\star \star}$ & $34.1^{\star \star *}$ & $18.1^{\star \star}$ & $-5.00 * \star$ & $22.8^{\star \star}$ & $17.3^{\star \star}$ & $2.04^{\star \star}$ \\
\hline L7 x L1 & $-12.2^{\star \star}$ & $57.0^{\star \star \star}$ & $58.9 \star \star$ & $66.4^{\star \star}$ & $-9.24^{\star \star}$ & $44.1^{\star \star}$ & $50.2^{\star \star}$ & $27.1^{\star *}$ \\
\hline L7 x L2 & $-12.0^{\star \star}$ & $71.0^{\star \star \star}$ & $63.9 * \star$ & $51.7^{\star \star}$ & $-8.60 \star \star$ & $48.9 * \star$ & $47.0^{\star \star \star}$ & $20.1^{\star \star}$ \\
\hline L7 x L3 & $-9.53^{\star \star}$ & $62.0^{\star \star \star}$ & $73.3^{\star *}$ & $37.4^{\star \star}$ & $-6.30 \star \star$ & $53.6^{\star \star}$ & $65.8^{\star \star}$ & 11.0 ** \\
\hline L7 x L4 & $-11.5^{\star \star}$ & $83.0^{\star \star \star}$ & $78.6^{\star \star}$ & $45.3^{\star \star}$ & $-5.88 * \star$ & $72.2^{\star \star}$ & 74. $9 \star \star$ & $17.5^{\star \star}$ \\
\hline L7 x L5 & $-9.32^{\star \star}$ & $36.0^{\star \star *}$ & $36.1^{\star \star}$ & $19.5^{\star \star}$ & $-8.55^{\star \star}$ & $31.3^{\star \star *}$ & $17.8^{\star \star}$ & 1.08 ** \\
\hline L7 x L6 & $-8.30 \star \star$ & $68.0^{\star *}$ & $60.4^{\star \star}$ & $39.3^{\star \star}$ & $-4.55^{\star \star}$ & $49.6^{\star \star}$ & $58.6^{\star \star}$ & 14.7 ** \\
\hline L8 x L1 & $-11.3^{\star \star}$ & $74.0^{\star \star *}$ & $45.0 \star \star$ & $31.2^{\star \star}$ & $-9.09 * \star$ & $60.2^{\star \star}$ & $43.6^{\star \star}$ & $27.5^{\star \star}$ \\
\hline L8 x L2 & $-10.6^{\star \star}$ & $85.0^{\star \star \star}$ & $73.8^{\star *}$ & $23.2^{\star \star}$ & $-6.34^{\star \star}$ & $61.8^{\star \star}$ & $49.6^{\star \star}$ & $21.4^{\star \star}$ \\
\hline L8 x L3 & $-9.9 \star \star$ & $76.0^{\star \star \star}$ & $66.4^{\star \star}$ & $18.4^{\star \star}$ & $-7.44^{\star \star}$ & $68.1^{\star \star}$ & $52.1^{\star \star}$ & $14.3^{\star \star}$ \\
\hline L8 x L4 & $-12.2^{\star \star}$ & $73.0^{\star \star \star}$ & $62.3^{\star \star}$ & $23.8^{\star \star}$ & $-7.44^{\star \star}$ & $64.0 \star \star$ & $58.0^{\star \star}$ & $20.9 \star \star$ \\
\hline L8 x L5 & $-9.24^{\star \star}$ & $40.0^{\star \star \star}$ & $25.7^{\star \star}$ & $12.9 * \star$ & $-7.69 * \star$ & $35.1^{\star \star}$ & $13.5^{\star \star}$ & $8.23^{\star *}$ \\
\hline L8 x L6 & $-9.09 * \star$ & $61.0^{\star \star \star}$ & $56.9 * \star$ & $23.4^{\star \star}$ & $-4.55^{\star \star}$ & $43.3^{\star \star}$ & $51.3^{\star \star}$ & 19.9 ** \\
\hline L8 x L7 & $-5.83^{\star \star}$ & $51.0^{\star *}$ & $47.9 * \star$ & $12.4^{\star}$ & $-5.04^{\star \star}$ & $50.3^{\star \star}$ & $41.1^{\star \star}$ & $17.5^{\star \star}$ \\
\hline L9 x L1 & $-11.6^{\star \star}$ & $68.0^{\star \star \star}$ & $60.1^{\star \star}$ & $64.5^{\star \star}$ & $-10.5^{\star \star}$ & $50.7^{\star \star}$ & $48.0^{\star \star}$ & $28.3^{\star \star}$ \\
\hline L9 x L2 & $-11.3^{\star \star}$ & $75.0^{\star * *}$ & $82.3^{\star \star}$ & $44.6^{\star \star}$ & $-5.88 \star \star$ & $65.1^{\star \star}$ & $67.0^{\star \star \star}$ & $19.5^{\star \star}$ \\
\hline L9 x L3 & $-11.7^{\star \star}$ & $75.0^{\star \star \star}$ & $75.4^{\star \star}$ & $38.7^{\star \star}$ & $-10.5^{\star \star}$ & $51.6^{\star \star}$ & $71.7 \star \star$ & 13.0 ** \\
\hline L9 x L4 & $-11.2^{\star \star}$ & $92.0^{\star \star \star}$ & $69.5^{\star \star}$ & $57.5^{\star \star}$ & $-7.66^{\star \star}$ & $67.0 \star \star$ & $62.3^{\star \star}$ & 23.0 ** \\
\hline L9 x L5 & $-7.88^{\star \star}$ & $53.0^{\star \star \star}$ & $44.9 * \star$ & $21.2^{\star \star}$ & $-5.13^{\star \star}$ & $23.2^{\star \star}$ & $23.1^{\star \star}$ & 3.24 ** \\
\hline L9 x L6 & $-8.12^{\star \star}$ & $68.0^{\star \star}$ & $59.3^{\star \star}$ & $41.6^{\star \star}$ & -2.27 & $55.8^{\star \star}$ & $53.9 \star \star$ & $17.1^{\star \star}$ \\
\hline L9 x L7 & $-11.9 * \star$ & $62.0 * \star$ & $58.9^{\star \star}$ & $41.9 * \star$ & $-10.1^{\star \star}$ & $34.4^{\star \star}$ & $55.3^{\star \star}$ & 19.0 ** \\
\hline L9 x L8 & $-12.7^{\star \star}$ & $60.0^{\star \star}$ & $57.7^{\star \star}$ & $23.2^{\star \star}$ & $-11.6^{\star \star}$ & $33.3^{\star \star}$ & $47.1^{\star \star}$ & $2.28 * *$ \\
\hline Cross & \multicolumn{4}{|c|}{ Mid parent heterosis } & \multicolumn{4}{|c|}{ Better parent heterosis } \\
\hline Code & $A D$ & $\mathrm{EH}$ & $\mathrm{PH}$ & NKPR & $A D$ & $\mathrm{EH}$ & $\mathrm{PH}$ & NKPR \\
\hline L10 x L1 & $-6.14^{\star \star}$ & $87.0^{\star \star \star}$ & $63.9 * \star$ & $42.4^{\star \star}$ & $-5.58 * \star$ & $84.8^{\star \star}$ & $55.6^{\star \star}$ & $23.9 * \star$ \\
\hline L10 x L2 & $-6.36 \star \star$ & $77.0^{\star *}$ & $73.7 \star \star$ & $34.4^{\star \star}$ & 0.0 & $65.4^{\star \star}$ & $55.2^{\star \star}$ & $18.3^{* *}$ \\
\hline L10 x L3 & $-9.09 \star \star$ & $82.0^{\star \star *}$ & $70.9 * \star$ & $30.3^{\star \star}$ & $-8.37 \star \star$ & $77.1^{\star \star}$ & $62.8^{\star \star *}$ & $12.2^{\star \star}$ \\
\hline L10 x L4 & $-8.67 \star \star$ & $97.0 * \star$ & $65.2^{\star \star}$ & $34.0 \star \star$ & $-5.58 \star \star$ & $93.4^{\star \star}$ & $62.5^{\star \star}$ & $17.5^{\star \star}$ \\
\hline L10 x L5 & -2.27 & $48.0^{\star \star}$ & $40.3^{\star \star}$ & $19.8^{\star \star}$ & 1.28 & $32.9^{\star \star}$ & $22.0^{\star \star}$ & $4.75^{\star \star}$ \\
\hline L10 x L6 & $-5.73^{\star \star}$ & $79.0^{* *}$ & $55.8^{\star \star}$ & $39.5^{\star \star}$ & 0.91 & $70.6^{\star \star}$ & $54.7^{\star \star}$ & $18.7^{\star \star}$ \\
\hline L10 x L7 & $-5.93^{\star \star}$ & $64.0 * \star$ & $61.8^{\star \star}$ & $40.9 * \star$ & $-3.36^{\star}$ & $51.9 \star \star$ & $61.1^{\star \star}$ & 21.1 ** \\
\hline L10 x L8 & $-8.32^{\star \star}$ & $63.0^{\star *}$ & $55.0 \star \star$ & $19.8^{\star \star}$ & $-6.61 \star \star$ & $51.7^{\star \star}$ & $48.5^{\star \star}$ & $2.83^{* *}$ \\
\hline L10 x L9 & $-7.42^{\star \star}$ & $78.0 * \star$ & $65.6^{\star *}$ & $31.2^{\star \star}$ & $-6.86^{\star \star}$ & $58.2^{\star \star}$ & $61.1^{\star \star}$ & $15.8^{\star *}$ \\
\hline Minimum & -14.5 & 36 & 25.7 & 12.4 & -13.6 & 22.8 & 13.5 & 1.08 \\
\hline Maximum & -2.27 & 115 & 95.2 & 66.4 & 1.28 & 97.5 & 74.9 & 28.3 \\
\hline$C D a_{0.05}$ & 0.8 & 5.82 & 7.45 & 3.39 & 1.31 & 9.5 & 12.2 & 2.27 \\
\hline$C D a_{0.01}$ & 1.06 & 7.71 & 9.87 & 4.49 & 1.73 & 12.6 & 16.1 & 3 \\
\hline
\end{tabular}

** and * significant at probability level of $\mathrm{P}<0.01$ and $\mathrm{P}<0.05$, respectively; $\mathrm{CD}=$ critical difference, $\mathrm{AD}=$ days to anthesis, $\mathrm{PH}=\mathrm{plant}$ height, $\mathrm{EH}=$ ear height, $\mathrm{NKPR}=$ number of kernels per rows, and Values with no asterisk are non-significant.

Citation: Abebe B, Ali WM, Chere AT (2020) Heterosis and character association of mid altitude adapted quality protein maize (Zea mays L.) hybrids at Bako, Western Ethiopia. Open J Plant Sci 5(1): 013-025. DOl: https://dx.doi.org/10.17352/ojps.000018 


\section{Association of characters}

Association of yield and other attributes assumed special importance as basis for selection of desired strain. Genetic correlation between different characters can be often also because of either.

\section{Genotypic and phenotypic correlation}

The values of estimated genotypic and phenotypic correlation coefficient between pair of characters in all possible combination are presented in Table 3. It was found that the genotypic correlation coefficients were higher than the corresponding phenotypic correlation coefficient for all traits in similar direction. Similar with the present study, Assaduzzaman [34], reported the genotypic correlation coefficients were higher than their corresponding phenotypic correlation for all traits studied on fourteen Lablab genotypes. The superiority of genotypic correlation coefficients indicated the less influence of environmental factors on expression of the traits and phenotypic correlation indicated the influence of environmental factors. Therefore, the result showed that a fairly strong inherent association between the characters studied Munawar, et al. [35].

Genotypic correlation coefficient is the heritable association between two variables. However, phenotypic correlation includes both phenotypic and environmental effect. Hence, significant phenotypic correlation without significant genotypic correlation has no value Bekele and Rao [36]. This explaining why genotypic correlation showed more significant difference between the pairs of traits than phenotypic correlation.

In this study, Grain Yield (GY) had exhibited strong significant positive genotypic and phenotypic correlation coefficient with Ear Length (EL), number of kernels row ${ }^{1}$ (NKPR), Ear Plant ${ }^{-1}(\mathrm{EPP})$. It had also highly $(\mathrm{P}<0.01)$ significant positive association with plant height $(\mathrm{PH})$ and Ear Height (EH) at phenotypic correlation level and with PH which had significant $(\mathrm{P}<0.05)$ positive association at genotypic level. Ear height and days to Anthesis (AD) had positive significant correlation with GY only at phenotypic level. Such results could help the breeder to select high grain yielder varieties through selection for one or more of these characters. The selection for long ear, more NKPR, EPP, taller PH and high ear placement may be accompanied by increasing maize GY. Similar results were reported by, Akeel, et al. [37] and Nzuve, et al, [38]. Other research work agreed with this study was showed that the strong correlation $\mathrm{EH}$ and $\mathrm{PH}$ had with grain yield suggested that, tall plants with high ear placement gave better yields to the shorter plants with lower ear placement Nzuve, et al. [38]. This indicated that by increasing these attributes in growth parameter especially plant height would help photosynthetic apparatus to synthesize more assimilates and hence production of higher yield.

It is only at phenotypic level, GY had significant $(\mathrm{P}<0.05)$ positive association with the $\mathrm{AD}$. In contrast to the present findings, Shashidhara [39], proven that, GY had negatively associated with $\mathrm{AD}$ at both genotypic and phenotypic level, whereas, PH, EL and NKPR had significant positive correlation again at both genotypic and phenotypic level. In addition, Number of Kernels Row (NKR) had positive correlation at phenotypic level with GY. This is according to various research work reported by Amini, et al. [40], Bekele and Rao [36] and Adesoji, et al. [41], GY had significant and positive association with EH, PH, EL, NKPR, NKR, 100 seed weight and total dry weight by the studied in different locations and year.

Table 3: Phenotypic (above diagonal) and genotypic (below diagonal) correlation coefficient of yield and yield related traits of 45 single crosses

\begin{tabular}{|c|c|c|c|c|c|c|c|c|c|c|c|c|c|c|c|c|}
\hline Traits & GY & AD & ASI & EH & PH & $\mathbf{R L}$ & EPP & EL & ED & NKPR & PA & EA & TLB & CLR & PLS & ER \\
\hline GY & & $0.19 *$ & -0.28 ** & $0.25^{\star \star}$ & $0.27^{\star \star}$ & $-0.19 *$ & $0.39 \star *$ & $0.40^{\star \star}$ & -0.08 & $0.32^{\star \star}$ & $-0.37^{\star \star}$ & $-0.39 * \star$ & -0.16 & -0.15 & $-0.19 *$ & $-0.25^{\star \star}$ \\
\hline$A D$ & 0.26 & & $-0.47^{\star \star}$ & $0.45^{\star \star}$ & $0.41^{\star \star}$ & $0.19 *$ & $0.58^{\star \star}$ & $0.19 *$ & $-0.29 \star *$ & 0.11 & 0.05 & -0.03 & -0.16 & -0.15 & $-0.26 \star \star$ & -0.09 \\
\hline ASI & $-0.34^{*}$ & $-0.51^{\star *}$ & & $-0.27 * *$ & -0.09 & 0 & $-0.45^{\star *}$ & -0.05 & 0.11 & -0.07 & 0.08 & -0.07 & 0.02 & -0.06 & 0.14 & 0.06 \\
\hline $\mathrm{EH}$ & 0.28 & $0.51^{\star \star}$ & $-0.37^{\star}$ & & $0.59 * \star$ & $0.27 \star \star$ & $0.43^{\star \star}$ & $0.28^{\star \star}$ & $-0.25^{\star \star}$ & 0.16 & 0.03 & 0.05 & -0.03 & 0.02 & -0.04 & -0.01 \\
\hline $\mathrm{PH}$ & $0.37 *$ & $0.55^{\star \star}$ & -0.17 & $0.68^{\star \star \star}$ & & $0.22^{\star}$ & $0.34^{\star \star}$ & $0.35^{\star \star}$ & $-0.27 * *$ & $0.24^{\star \star \star}$ & 0 & $-0.22^{\star *}$ & -0.05 & -0.06 & 0.01 & -0.1 \\
\hline RL & -0.22 & 0.25 & 0.05 & $0.33^{*}$ & 0.26 & & 0.1 & 0.12 & -0.14 & 0.07 & $0.23^{\star \star}$ & 0.15 & 0.04 & 0.08 & $-0.18^{*}$ & -0.1 \\
\hline EPP & $0.43^{\star \star}$ & $0.71^{\star \star}$ & $-0.55^{\star \star}$ & $0.56^{\star \star}$ & $0.47^{\star \star}$ & 0.24 & & 0.11 & $-0.20^{\star}$ & 0.07 & -0.03 & -0.05 & -0.04 & -0.09 & -0.16 & $-0.17^{*}$ \\
\hline EL & $0.40^{\star \star}$ & 0.28 & -0.03 & $0.32^{\star}$ & $0.43^{\star \star}$ & 0.08 & 0.18 & & $-0.42^{\star \star}$ & $0.63^{\star \star *}$ & -0.13 & $-0.21^{*}$ & -0.13 & 0.04 & -0.07 & 0.05 \\
\hline ED & 0.15 & $-0.59 * *$ & 0.2 & $-0.47^{\star \star}$ & $-0.34^{\star}$ & $-0.42^{\star \star}$ & $-0.5^{\star \star}$ & $-0.4^{\star \star}$ & & $-0.55^{\star \star}$ & -0.11 & 0.02 & -0.13 & -0.04 & 0.03 & 0.0 \\
\hline NKPR & $0.48^{\star \star}$ & 0.21 & -0.11 & 0.18 & 0.27 & -0.01 & 0.16 & $0.74^{\star \star}$ & -0.21 & & -0.20 * & $-0.19 *$ & 0.01 & -0.02 & -0.05 & -0.03 \\
\hline PA & $-0.57^{\star *}$ & 0.12 & 0.08 & -0.04 & -0.1 & 0.29 & -0.07 & -0.18 & $-0.37^{*}$ & $-0.33^{*}$ & & $0.42^{\star \star}$ & 0.03 & 0 & 0.01 & $0.22^{\star \star}$ \\
\hline EA & $-0.45^{\star \star}$ & -0.03 & -0.12 & 0.09 & $-0.33^{*}$ & 0.17 & -0.06 & -0.26 & -0.21 & -0.26 & $0.58^{* *}$ & & 0.03 & 0.16 & 0.11 & $0.4^{\star \star}$ \\
\hline TLB & $-0.37 *$ & -0.21 & 0.12 & -0.04 & -0.09 & 0.02 & -0.12 & $-0.45^{\star \star}$ & 0.11 & $-0.44^{\star \star}$ & 0.26 & 0.21 & & 0.07 & 0.04 & -0.11 \\
\hline CLR & $-0.32^{\star}$ & -0.23 & -0.1 & 0.03 & -0.08 & 0.12 & -0.08 & -0.11 & -0.11 & -0.12 & 0.16 & 0.28 & 0.23 & & $0.44^{\star \star}$ & 0.03 \\
\hline PLS & $-0.31^{*}$ & $-0.35^{*}$ & 0.19 & 0 & -0.02 & -0.14 & -0.24 & -0.15 & -0.05 & -0.11 & -0.02 & 0.2 & 0.11 & $0.58^{\star \star}$ & & 0.16 \\
\hline ER & $-0.37^{*}$ & -0.09 & 0.09 & 0.02 & -0.17 & -0.08 & -0.26 & 0.12 & -0.25 & 0.04 & $0.37 *$ & $0.44^{\star *}$ & -0.04 & -0.07 & 0.14 & \\
\hline
\end{tabular}

** and * significant at probability level of $P<0.01$ and $P<0.05$, respectively; GY: Grain yield, EL: Ear Length, ED: Ear Diameter; EA: Ear Aspect: NKP: Number of Kernels Row; NKPR: Number of Kernels Per Rows; AD: days to anthesis; ASI: Anthesis Silking Interval; PH: Plant height; EH: Ear Height; EPP: Number of Ears Per Plant; PA: Plant Aspect; RL: Root Lodging; ER: Ear Rot; TLB: Turcicum Leaf Blight; PLS: Pheasphorial Leaf Spot and Values with no asterisk are non-significant.

Citation: Abebe B, Ali WM, Chere AT (2020) Heterosis and character association of mid altitude adapted quality protein maize (Zea mays L.) hybrids at Bako, Western Ethiopia. Open J Plant Sci 5(1): 013-025. DOI: https://dx.doi.org/10.17352/ojps.000018 
In disagreement of the present findings, Aminu and Izge [42], reported $\mathrm{AD}, \mathrm{EH}$ and $\mathrm{PH}$ had exhibited negative correlation with GY and suggested that these traits were not closely associated and therefore, they may not be jointly selected. The difference results were found due to the genotypes was evaluated under drought condition. On the other hand, Berhanu [28], Bello, et al. [43] and Kinfe, et al. [44], reported that, GY had significant and positive phenotypic correlation with $\mathrm{EH}$, PH, EL, EPP, NKPR and ADin agreement with this study and proven the existence of direct association between the traits.

Other traits i.e., plant Aspect (PA), Ear Aspect (EA) and Anthesis Silking Interval (ASI) had strongly significant negative association with grain yield at genotypic and phenotypic level, except ASI had moderately significant at phenotypic level. Where, ASI, Ear Rot (ER) and Phaeosphaeria Leaf Spot (PLS) had significant negative association at genotypic and phenotypic level, and Turcicum Leaf Blight (TLB) had at genotypic level. This revealed that, by decreasing these attributes, could consistently increase grain yield. The selection made to improve yield of maize genotype may be useful through decreasing these traits. In line with the current study, Hadji [45], observed GY had exhibited significant and negative association with number of diseased ears. In agreement with this result, Kinfe, et al. [44], reported that, GY had significant and negative association with ASI. Other research findings reported by Aminu and Izge [42], exhibited ASI; bad Husk Cover (HC) and EPP had showed significant negative correlation with GY at genotypic level. This showed that, these genotypes had short days to ASI, husked cobs and a smaller number of EPP had potential to give high grain yield.

However, non-significant correlations were observed between GY and other traits due to masking effects of environment. This is indicating that selection for increase the level of these traits may not bring significant change in GY

\section{Path coefficient}

Phenotypic and genotypic path coefficient analysis is a proved effective means of separating direct and indirect effect of associated traits on yield. The analysis using grain yield as a dependent variable was conducted for the traits that exhibited significant genotypic and phenotypic association with yield. The phenotypic and genotypic direct (bold) and indirect effects of twelve and eleven traits on grain yield were presented in Tables 4,5 below, respectively.

Days to Anthesis (AD) had a negative direct effect on Grain Yield (GY) at phenotypic level. The correlation coefficient between the two traits was positive and significant $(\mathrm{P}<0.05)$. Moreover, the negative indirect contribution of $\mathrm{AD}$ to $\mathrm{GY}$ was through number of Ears Per Plant (EPP) at phenotypic level. Since correlation is positive, but the direct effect is negative, the indirect effects seem to be cause for correlation. This result agrees with some earlier findings, Saleem [46], reported AD had negative direct on grain yield by the study on ten $\mathrm{S}_{1}$ families evaluated under irrigated and drought condition. Therefore, in such situations, the indirect causal factors are to be considered simultaneously for selection.

At both genotypic and phenotypic level, Anthesis Silking Interval (ASI) had showed highly significant negative correlation and negative direct effect on grain yield. Ear Height (EH) had highly significant positive correlation and direct effect on GY at phenotypic level; while, the genotypic correlation is positive and statistically non-significant. In contrast to this finding, Muhammad et al. [15] reported that, EH had negative direct effect on GY by the study on eight local hybrids Maize. The different result was obtained may be due to the use of different source materials for the study. In agreement with the current finding, Hadji [45], observed, EH had exerted positive direct effects on GY at phenotypic level.

Other works agreed with this finding reported by Munawar, et al. [35], showed that the number of kernels row ${ }^{-1}$ (NKPR) had positive direct effect followed by EH for seven exotic hybrids maize sourced from different seed companies in Pakistan. Similarly, Sreckov, et al. [47], they reported EH had positive direct effect on GY, however, it was non-significant.

Table 4: Direct and indirect effects of yield contributing traits, phonological and growth and disease parameters on yield at phenotypic level.

\begin{tabular}{|c|c|c|c|c|c|c|c|c|c|c|c|c|c|}
\hline Traits & AD & ASI & EH & PH & RL & EPP & EL & NKPR & PA & EA & PLS1 & ER & Rp \\
\hline$A D$ & -0.190 & 0.072 & 0.05 & 0.03 & -0.047 & 0.171 & 0.055 & 0.005 & -0.008 & 0.004 & 0.039 & 0.010 & 0.26 \\
\hline ASI & 0.09 & -0.153 & -0.031 & -0.006 & 0.00 & -0.132 & -0.014 & -0.003 & -0.011 & 0.011 & -0.021 & -0.007 & -0.34 \\
\hline $\mathrm{EH}$ & -0.09 & 0.042 & 0.112 & 0.043 & -0.068 & 0.127 & 0.080 & 0.007 & -0.004 & -0.007 & 0.007 & 0.002 & 0.28 \\
\hline $\mathrm{PH}$ & -0.08 & 0.014 & 0.067 & 0.072 & -0.055 & 0.099 & 0.100 & 0.011 & 0.00 & 0.033 & -0.001 & 0.012 & 0.37 \\
\hline $\mathrm{RL}$ & -0.04 & 0.00 & 0.03 & 0.016 & -0.252 & 0.029 & 0.035 & 0.003 & -0.034 & -0.022 & 0.028 & 0.011 & -0.26 \\
\hline EPP & -0.11 & 0.069 & 0.049 & 0.024 & -0.025 & 0.294 & 0.031 & 0.003 & 0.004 & 0.008 & 0.024 & 0.020 & 0.43 \\
\hline EL & -0.04 & 0.007 & 0.032 & 0.025 & -0.031 & 0.032 & 0.286 & 0.029 & 0.020 & 0.031 & 0.011 & -0.006 & 0.40 \\
\hline NKPR & -0.02 & 0.011 & 0.018 & 0.017 & -0.018 & 0.02 & 0.18 & 0.045 & 0.029 & 0.028 & 0.008 & 0.003 & 0.48 \\
\hline PA & -0.01 & -0.012 & 0.003 & 0.00 & -0.057 & -0.008 & -0.038 & -0.009 & -0.149 & -0.062 & -0.001 & -0.027 & -0.57 \\
\hline EA & 0.01 & 0.011 & 0.005 & -0.016 & -0.036 & -0.015 & -0.06 & -0.008 & -0.062 & -0.15 & -0.016 & -0.048 & -0.45 \\
\hline PLS1 & 0.05 & -0.021 & -0.005 & 0.00 & 0.046 & -0.046 & -0.021 & -0.002 & -0.001 & -0.016 & -0.151 & -0.019 & -0.31 \\
\hline ER & 0.02 & -0.009 & -0.002 & -0.007 & 0.024 & -0.05 & 0.014 & -0.001 & -0.033 & -0.060 & -0.024 & -0.120 & -0.37 \\
\hline
\end{tabular}

Residual effects $=69.5 \%$

AD: days to anthesis; ASI: Anthesis Silking Interval; PH: Plant height; EH: Ear Height; EPP: Number of Ears Per Plant; PA: Plant Aspect; RL: Root Lodging; ER: Ear Rot; TLB: Turcicum Leaf Blight; PLS: Pheasphorial Leaf Spot; ER: Ear Rot and Rp: Phenotypic correlation.

Citation: Abebe B, Ali WM, Chere AT (2020) Heterosis and character association of mid altitude adapted quality protein maize (Zea mays L.) hybrids at Bako, Western Ethiopia. Open J Plant Sci 5(1): 013-025. DOI: https://dx.doi.org/10.17352/ojps.000018 
Table 5: Direct and indirect effects of yield contributing traits, phonological and growth and disease parameters on grain yield at genotypic level enhance.

\begin{tabular}{|c|c|c|c|c|c|c|c|c|c|c|c|c|}
\hline Traits & ASI & PH & EPP & EL & NKPR & PA & EA & TLB & CLR & PLS1 & ER & Rg \\
\hline ASI & -0.190 & -0.018 & -0.066 & -0.003 & -0.019 & -0.026 & 0.00 & -0.008 & 0.020 & -0.012 & -0.018 & -0.34 \\
\hline PH & 0.03 & 0.106 & 0.056 & 0.042 & 0.047 & 0.034 & -0.001 & 0.006 & 0.017 & 0.001 & 0.034 & 0.37 \\
\hline EPP & 0.10 & 0.049 & 0.121 & 0.017 & 0.027 & 0.024 & 0.00 & 0.008 & 0.015 & 0.015 & 0.052 & 0.43 \\
\hline EL & 0.01 & 0.045 & 0.021 & 0.10 & 0.129 & 0.060 & -0.001 & 0.031 & 0.022 & 0.009 & -0.025 & 0.40 \\
\hline NKPR & 0.02 & 0.029 & 0.019 & 0.073 & 0.175 & 0.113 & -0.001 & 0.030 & 0.024 & 0.007 & -0.008 & 0.48 \\
\hline PA & -0.02 & -0.011 & -0.009 & -0.018 & -0.058 & -0.338 & 0.002 & -0.018 & -0.032 & 0.001 & -0.075 & -0.57 \\
\hline EA & 0.02 & -0.034 & -0.007 & -0.026 & -0.045 & -0.194 & 0.003 & -0.015 & -0.057 & -0.012 & -0.089 & -0.45 \\
\hline TLB & -0.02 & -0.01 & -0.014 & -0.044 & -0.077 & -0.088 & 0.001 & -0.069 & -0.046 & -0.007 & 0.009 & -0.37 \\
\hline CLR & 0.02 & -0.009 & -0.009 & -0.011 & -0.021 & -0.053 & 0.001 & -0.016 & -0.203 & -0.036 & 0.014 & -0.32 \\
\hline PLS1 & -0.04 & -0.002 & -0.028 & -0.015 & -0.019 & 0.007 & 0.001 & -0.007 & -0.117 & -0.062 & -0.028 & -0.31 \\
\hline ER & -0.02 & -0.018 & -0.031 & 0.012 & 0.007 & -0.126 & 0.001 & 0.003 & 0.014 & -0.008 & -0.202 & -0.37 \\
\hline
\end{tabular}

Residual effects $=58.8 \%$

ASI: Anthesis Silking Interval; PH: Plant Height; EPP: Number of ears plant ${ }^{-1}$; EL: Ear length; NKPR: Number of kernels arow ${ }^{1}$; PA: Plant Aspect; EA: Ear Aspect; TLB: Turcicum Leaf Blight; CLR: Common Leaf Rust; PLS: Phaeosphaeria Leaf Spot; ER: Ear Rot and Rg=Genotypic correlation.

The magnitude of direct effect of Plant Height $(\mathrm{PH})$ on grain yield was very small at phenotypic level, where both genotypic and phenotypic correlations were positive and statistically significant. Therefore, the direct effect and correlation coefficient explain the true association between the two characters and selection for having tallest plant feature will improve GY. Similar with the current study, Adesoji, et al. [41], reported that, growth parameters such as plant height had positive direct effect on GY by the study on two maize varieties at Nigeria. However, there is a contrasting finding with the present findings was reported by Munawar, et al. [35] and Zarei, et al. [48] revealed that, PH, Ear Length (EL) and number of kernel row (NKR) had negative direct effect on GY and concluded that, the improvement of these traits is essential before selecting them for high GY. These results showed that the selection of these characters except number of grains per row (NKPR) would be less effective for improving grain yield.

Root Lodging $(\mathrm{RL})$ had significant $(\mathrm{P}<0.05)$ negative both genotypic and phenotypic correlation coefficient; however, it was non-significant correlation coefficient at genotypic level. This showed that, RL had adverse effect on GY at phenotypic level. The other very important salient components of GY revealed traits highly significant and positive correlation at both genotypic and phenotypic level were number of ears plant $^{-1}$ (EPP), EL and NKPR. All of them had revealed positive direct effect as well; however, NKPR had negligible direct effect at phenotypic level. In agreement with the current result, Hadji [45], reported that, number of EPP, EL, and NKPR had positive direct effects on grain yield at both phenotypic and genotypic level.

Moreover, the positive indirect contribution of the number $\mathrm{EPP}$ to GY were through $\mathrm{AD}$ and $\mathrm{EH}$. Whereas, the negative counter balance of the NKPR to GY was via ASI at phenotypic level. The other positive indirect contribution of EL to GY was via PH and the NKPR at phenotypic level. Where, the positive indirect effect of number of kernels per row was enhanced through ear length at genotypic level. This means that a slight increase in one of the above traits may directly contributed to grain yield.
In agreement of the present study, Muhammad, et al. [15], reported similar results and they concluded that, the effective selection for superior genotypes is possible considering, ear length and number of kernels row ${ }^{-1}$. Researchers like, Rafiq, et al. [49], Zarei, et al. [48]; Adesoji, et al. [41] and Kinfe, et al. [44], also reported similar result with the current findings for EL and NKPR. These traits are therefore, very important components of GY and should be given high emphasis in any selection process aimed at improving grain yield in maize.

In the extension of GY components, Plant Aspect (PA) and Ear Aspect (EA) had highly significant negative genotypic and phenotypic correlation coefficient. The direct effect of PA on GY was negative at both genotypic and phenotypic level. However, EA had negative direct effect at phenotypic level, and it had negligible positive direct effect on GY at genotypic level. The negative direct effect of PA on GY was counter balanced via positive indirect effects of NKPR and enhanced through negative indirect effect of EA. It is therefore, concluded that these GY related agronomic parameters could be considered as important selection criteria in improving hybrid and open pollinate maize varieties Bello, et al. [43].

Turcicum Leaf Blight (TLB) had a positive lesser direct effect on GY at genotypic level. The genotypic correlation coefficient between the traits and GY was statistically significant and negative. The correlation explains, low disease severity level or tolerant genotypes had a potential to yield more. While the direct effect was negligible, the indirect effect seemed to be cause of correlation. In such conditions, the other indirect causal factors are to be considered simultaneously for selection.

Common Leaf Rust (CLR) had negative direct effect on GY at genotypic level. The genotypic correlation coefficient was negative as well. On the other hand, phenotypic correlation showed non-significant association with GY. The negative indirect effect CLR exerted on GY was enhanced by negative indirect effect through Phaeosphaeria Leaf Spot (PLS). The correlation results explain that, improving the resistance level of genotypes was boosting GY. Therefore, selecting of 
genotypes for resistant to CLR could be effective by considering indirect causal factors at the same time.

The other maize foliar disease was PLS which had significant negative genotypic and phenotypic correlation coefficient with GY. In addition, the magnitude of the direct effect was negative at both genotypic and phenotypic level. The correlation coefficient at both genotypic and phenotypic level showed that, the genotypes with minimum disease reaction score could have a potential to boost the yield. Again, the selection for disease resistant high yielding hybrids should consider the indirect causal factors which could enhance yield and reduce disease development.

The other bad character encountered GY was Ear Rot disease (ER). It had negative and highly significant $(\mathrm{P}<0.01)$ correlation at phenotypic level and significant $(\mathrm{P}<0.05)$ correlation at genotypic level. At both genotypic and phenotypic level, it had negative direct effect on GY. Like other disease parameter, the selection of genotypes with a smaller number of ears susceptible to ER could help to get the varieties giving high yield and vice-versa. Therefore, the selection for ER free hybrids will be valuable if it considered other indirect causal factors in addition to the disease.

The residual effect estimation of $69.51 \%$ indicated that the causal variables explained only about $30.49 \%$ of the variability in grain yield and the remaining $69.51 \%$ of variability stays unexplored at phenotypic level. On the other hand, the residual effect of $58.84 \%$ exhibited that the fundamental variables elucidated only about $41.16 \%$ of the variability in grain yield and about $58.84 \%$ of the variability remain uninvestigated at genotypic level of path coefficient analysis. In contrast with the current study, Hadji [45], reported small residual effect $44 \%$ at phenotypic and $11 \%$ very small genotypic level for QPM inbred lines evaluated at the same location with the current study. Similary, Adesoji, et al. [41] and Kinfe, et al. [44], found small residual effects as compared with the current finding.

The reason seems to be very low variability in the present study were due to non-significant correlations coefficient of the remaining traits with the causal factor, GY at both genotypic and phenotypic level. Besides, some other factors which have not been considered here need to be included in this analysis to account fully for the remaining variation in grain yield. It means that, the high value obtained in residual effects indicated that other factors and variables not considered in this study were of high effect on grain yield. Similar with this work, Oad, et al. [50] found the maximum (79\%) residual effect for thirty varieties and advanced lines of Rice belonged to early to medium maturity collected from Philippines. In support of the current findings, Yucel and Anlarsal [51] reported 78.7 percent of residual effect for twenty-two selected $\mathrm{F}_{4}$ Chickpea genotypes obtained from ICARDA. However, it was not reported for maize, Abebe [52,53], found maximum residual effects ( 72.48 percent) at phenotypic level for Ethiopian Mustard.

\section{Summary and conclusion}

In this study, almost all crosses were showed positive and highly significant mid and better parent heterosis for all traits assessed. In both cases, the same cross, $\mathrm{L} 4 \times \mathrm{L} 2$ and $\mathrm{L} 5 \times \mathrm{L} 3$ consistently manifested the highest and lowest percentage of heterosis respectively.

The estimation of phenotypic and genotypic correlation coefficient between pair of characters in all possible combination revealed the presence of a true association among traits. At phenotypic correlation level, GY had significant positive association with, EL, NKPR, AD, PH, EH, EPP and TGB, However, it had significant and negative correlation with EA, ASI, PA, RL, ER and PLS. The positive phenotypic correlation showed as by increasing these traits there is a possibility to increase GY while the negative association indicated as, increasing effects of these traits may resulted in decreasing GY considerably.

Similarly, at genotypic level, GY had significant positive correlation with, EL, NKPR, PH and EPP which indicated that, breeding program engaged to increase these traits will increase GY production. On the other hand, it had significant and negative correlation with EA, PA, ER, TLB and PLS. This showed that, by decreasing the effects of bad traits, invariably increase yield and since little score was given for highly attractive cobs and for plants with good stature.

Traits like, EPP and EL had the maximum positive direct contribution to GY at both genotypic and phenotypic level. Whereas, PA, ER and ASI had negative direct effect on grain yield at both genotypic and phenotypic. In addition, $\mathrm{PH}$ and EPP had positive direct contribution at both genotypic and phenotypic correlation, however, EA and $\mathrm{EH}$ had positive direct effect on GY at genotypic and phenotypic correlation level respectively. Where, $\mathrm{AD}, \mathrm{RL}$ and $\mathrm{EA}$ had negative direct influences on GY at phenotypic level and TLB and CLR had negative direct effect on GY at genotypic level. So, the positive and negative direct effects were nullified and enhanced by their respective negative and positive indirect effect to make counter balanced the effect on GY via other characters indirectly.

In general, it can be concluded that the research results suggested the importance of continuous and extensive research on quality protein maize best fit to mid altitudes of the country to generate information that can be used to design breeding strategy.

\section{Acknowledgements}

We gratefully, acknowledge the Ethiopian Institute of Agricultural Research (EIAR) and International Maize and Wheat Improvement Center (CIMMYT) for the research financial and support. In addition, we are deeply indebted to all Bako National Maize Research Center staff for their invaluable help during the research work in general.

\section{References}

1. Centeral Statistical Agency (CSA) (2019) Agricultural Sample Servey for 2018/2019. Report on area and production of major crops (privet peasant holdings and Meher season). Statistical Bulletin. Addis Abeba, Ethiopia.

2. Prasana BM, Vasal SK, Kassahun B, Singh NN (2001) Quality Protein Maize Current Sci 81: 1308-1319. Link: https://bit.ly/2Wcbaoj

Citation: Abebe B, Ali WM, Chere AT (2020) Heterosis and character association of mid altitude adapted quality protein maize (Zea mays L.) hybrids at Bako, Western 
3. Vasal S K (2000) The quality Protein Maize Story. Food Nutr Bull 445-450. Link https://bit.ly/3aOgrYG

4. Nuss ET, Tanumihardjo SA (2010) Maize: a paramount staple crop in the context of global nutrition. Food Sci 9: 417-436. Link: https://bit.ly/2y2oeF4

5. Atlin GN, Palacios N, Babu R, Twumasi-Afriye S, De Groote H, et al. (2011) Quality protein maize: Progress, impact, and prospects. Plant Breeding Rev 34 83-130. Link: https://bit.ly/2yXKFLm

6. Denic D, Ignjatovic M, Goran S, Ksenija M, Sladjana Z, et al. (2012) Role of genetic resources from different geographic and climatic regions in simultaneous breeding for high Quality Protein Maize (HQPM) and stress tolerance. Genetika 44: 13-23. Link: https://bit.ly/2KLKQw2

7. Mertz ET,Veron O, Batesand LS, Nelson OE (1965) Grow of rats fed opaque-2 maize. Crop Sci 148: 1741-1742. Link: https://bit.ly/2KKOMNC

8. Nelson $\mathrm{OE}(1969)$ Genetic modification of protein quality in plant. Advanced Agronomy 21: 171-194. Link: https://bit.ly/2W8oKJF

9. Vasal SK, Villegas E, Tang CY (1984) Recent advances in the development of quality protein maize at the Centro Internacional de Mejoramiento de Maiz y Trigo. In: Cereal grain protein improvement. Vienna: International Atomic Energy Agency, 169-189. Vasal SK, Srinivasan G, Pandey S, Gonzalez CF Crossa J, et al. (1993) Heterosis and combining ability of CIMMYT's quality protein maize germplansm: Lowland tropical. Crop Sciences 33: 46-51. Link: https://bit.ly/3fOwB4F

10. Rissi R, Hallauer AR (1991) Evaluation of four testers for evaluating Maize (Zea mays L.) lines in a hybrid development program. Rev. Brasil Genetics 14: 467 481. Link: https://bit.ly/2xpDoE0

11. George A (2007) Principles of plant genetics and breeding, $1^{\text {st }}$ edition Blackwell Publishing Ltd 485.

12. Hallauer AR, Miranda F J B (1988) Quantitative Genetics In Maize. lowa State Univ Press. Ames. Link: https://bit.ly/2YpQFXY

13. Gomez AK, Gomeze AA (1984) Statistical Procedure for Agricultural Research $2^{\text {nd }}$ edition. John Wiley and Sons. New York. Link: https://bit.ly/2WbhbSn

14. Falconer DS, Mackay LFC (1996) Introduction To Quantitative Genetics. $4^{\text {th }}$ edition. Longman, Essex, England. Link: https://bit.ly/3aKpGsJ

15. Muhammad BA, Muhammad ST, Amer H, Tariq M, Muhammad S (2003) Character Association and Path Coefficient Analysis of Grain Yield and Yield Components Maize (Zea mays L.). Pak J Biol Sci 6: 136-138. Link: https://bit.ly/2zKaT4H

16. Saleem M, Ahsan M Aslam M and Majeed A(2008) Comparative evaluation and correlation estimates for grain yield and quality attributes in Maize. Pak Botany 40: 2361-2367. Link: https://bit.ly/2zM7ORL

17. Dewey DI, Lu KH (1959) A Correlation and Path-Coefficient Analysis of Components of Crested Wheat grass Seed Production. Agronomy Journal 51: 515-518. Link: https://bit.ly/2VNGGKn

18. Singh HN, Srivastava JP, Prasad R (1977) Genetic variability and correlation studies in bittergourd. Indian J Agril Scientist 47: 604-607. Link: https://bit.ly/3f60ikP

19. Patterson HD, Williams ER (1976) A new class resolvable incomplete block designs. Biometrika 63: 83-92. Link: https://bit.ly/2VODfD

20. Cochran WG, Cox GM (1960) Experimental designs. John Wiley and Sons, Inc., New York.

21. Singh RK, Chaudhary BD (1985) Biometrical methods in quantitative genetic analysis. Kalyani Publishers New Dehli, India.

22. Al-Jibouri HA, Miller PA, Robinson HF (1958) Genetic and environmental variances and covariances in upland cotton cross of interspecific origin. Agron J 50: 633-37. Link: https://bit.ly/2VMlq6S
23. Habtamu Z (2015) Heterosis and Combining Ability for Grain Yield and Yield Component Traits of Maize in Eastern Ethiopia. Current Agricul Res J 3: 118 127. Link: https://bit.ly/3d50Sxn

24. Ojo GO, Adedzwa SDK, Bello LL (2007) Combining Ability Estimates and Heterosis for Grain Yield and Yield Components in Maize (Zea mays L.) J Sustainable Develop Agriculture Environ 3: 49-57. Link: https://bit.ly/35g7gzO

25. Abdel-Moneam MA, Attia AN, EL-Emery MI, Fayed EA (2009) Combining ability and heterosis for some agronomic traits in crosses of maize. Pak J Bio Sci 12 433-438. Link: https://bit.ly/3aTLOvT

26. Dagne W, Bindiganavile V (2013) Association of Parental Genetic Distance with Heterosis and Specific Combining Ability in Quality Protein Maize. Euphytica 191: 205-216. Link: https://bit.ly/2YhHUPL

27. Bello OB, Olawuyi OJ (2015) Gene Action, Heterosis, correlation and regression estimates in developing hybrid cultivars in Maize. Tropical Agriculure 92: 102 117. Link: https://bit.ly/3aKsrdz

28. Berhanu T (2009) Heterosis and combining ability for yield related parameters and stover quality traits for food-feed in maize (Zea mays L.) Adapted to the mid-altitude agro-ecology of ethiopia. MSc. Thesis, Haramaya University, Haramaya, Ethiopia. Link: https://bit.ly/2WdkiZY

29. Gudeta N (2007) Heterosis and combining abilities in QPM versions of early generation highland Maize (Zea mays L.) inbred lines. M.Sc. Thesis. Presented to the School of Graduate Studies, Alemaya University, Ethiopia.

30. Jehan SA, Muhammad M, Muhammad AK (2011) Heterosis studies in dialle crosses of maize. Sarhad Journal of Agriculture, 27(2): 207-211. Link: https://bit.ly/2SIKRuQ

31. Bayisa A, Hussein M, Habtamu Z (2005) Combining ability of highland maize inbred lines. Ethiopia. J Agricult Sci 18: 181-189. Link: https://bit.ly/3d4760v

32. Dagne W, Habtamu Z, Labuschagne MT, Temam H, Singh H (2007) Heterosis and combining ability for grain yield and its components in selected maize inbred lines. South African Jounal of Plant Soil 24: 133-137.

33. Iqbal M, Khan K, Rahman H, Khalil IH, Sher H and Bakht J (2010) Heterosis for Morphological Traits in Subtropical Maize (Zea mays L.). Maydica 55: 41-48. Link: https://bit.ly/3bQ2yun

34. Asaduzzaman MJ, Bhuiyan H, Hossain MA, Sharif-AL-R (2014) Correlation and path coefficient analysis of fourteen different genotypes of lablab bean (Lablab purpureus L.). Bangladesh Journal of Plant Breeding Genetics 27: 37 44. Link: https://bit.ly/3bRjlYy

35. Munawar M, Muhammad S, and Ghazanfar H (2013) Correlation and path analysis of grain yield components in exotic Maize (Zea mays L.) Hybrids. Int J Sci 12: 22-27. Link: https://bit.ly/2VMeLum

36. Bekele A, Nageshwar RT (2014) Estimates of heritability, genetic advance and correlation study for yield and it's attributes in Maize (Zea mays L.). Journal of Plant Sciences 2: 1-4. Link: https://bit.ly/2zBJx0m

37. Akeel A, Hasan KA, Samir A Al-A (2008) Breeding and Potentials of High Biomass Rice Varieties for Bioenergy Production in Japan. Agriculture and Biology Journal of North America 1: 11-13.

38. Nzuve F, Githiri S, Mukunya DM and GethiJ (2014) Genetic variability and correlation studies of grain yield and related agronomic traits in Maize. Journal of Agricultural Sciences 6: 166-176. Link: https://bit.ly/3f6MCFU

39. Shashidhara (2008) Early generation testing for combining ability in maize (Zea mays L.). M.Sc. Thesis, Presented to University of Agricultural Science. Dharwad. Link: https://bit.ly/2zBKt4S

40. Amini Z, Mahmood K, Sadallah H (2013) Correlation and path coefficient analysis of seed yield related traits in Maize. International Journal of Agricultural and Crop Sciences 2217-2220. Link: https://bit.ly/2SBm7iD

Citation: Abebe B, Ali WM, Chere AT (2020) Heterosis and character association of mid altitude adapted quality protein maize (Zea mays L.) hybrids at Bako, Western Ethiopia. Open J Plant Sci 5(1): 013-025. DOl: https://dx.doi.org/10.17352/ojps.000018 
41. Adesoji AG, Abubakar IU, Labe DA (2015) Character association and path coefficient analysis of maize (Zea mays $L$.) grown under incorporated legumes and nitrogen. Journal of Agronomy 14: 158-163. Link: https://bit.ly/3f6heHB

42. Aminu D, Izge U (2012) Heritability and correlation estimates in maize (zea mays I.) under drought conditions in Northern Guinea and Sudan Savannas of Nigeria. World Journal of Agricultural Sciences 8: 598-602. Link: https://bit.ly/2ydse5p

43. Bello OB, Abdulmaliq SY, Afolabi MS and Ige SA (2010) Correlation and path coefficient analysis of yield and agronomic characters among open pollinated maize varieties and their $F_{1}$ hybrids in a diallel cross. Afr J Biotechnol 9: 26332639. Link: https://bit.ly/2VPlq7/

44. Kinfe HI, Getachew A, Legesse W, Yemane T (2015) Correlation and path coefficient analysis of grain yield and yield related traits in Maize (Zea mays $L$.) hybrids at Bako. Journal of Biology Agricultur and Healthcare 5: 44-53. Link: https://bit.ly/2xohYXO

45. Hadji T (2004) Combining ability analysis for yield and yield related traits in quality protein maize (QPM) inbred lines. An M.Sc. Thesis Presented to Schoo of Graduate Studies of Alemaya University.

46. Saleem AR (2007) Correlation and path coeffiecient analysis in maize (Zea mays L.). J Agricul Res 45: 177-183. Link: https://bit.ly/2KR5ACx

47. Srećkov Z, Jan B, Aleksandra N and Ivica Đ (2010) Correlation and Path
Coefficient Analysis of Morphological Traits of Maize (Zea mays L.). Res J Agricult Sci 42: 292-296. Link: https://bit.ly/3aPh7g

48. Zarei B, Danial K, Alireza PA and Farhad S (2012) Correlation and Path Coefficient Analysis for Determining Interrelationships among Grain Yield and Related Characters in Corn Hybrids (Zea mays L.). Int J Agricul Crop Sci 4 1519-1522. Link: https://bit.ly/3aMVmh5

49. Rafiq C, Muhammad MR, Amer H (2010) Studies on Heritability, Correlation and Path Analysis in Maize (Zea mays L.). J Agricul Res 48: 35-38. Link: https://bit.ly/2WcQmNK

50. Oad FC, Samo MA, Zia-Ul-Hassan Sta PC, Oad NL (2002) Correlation and path analysis of quantitative characters of Rice ratoon cultivars and advance lines. Int J Agricul Biol 4: 204-207. Link: https://bit.ly/2Yk5wTS

51. Yucel OD, Anlarsal AE (2010) Determination of selection criteria with path coefficient analysis in chickpea (Cicer arietinum L.) breeding. Bulgarian $J$ Agricul Sci 16: 42-48. Link: https://bit.ly/3f3PFyP

52. Abebe D (2006) Genetic variability and association among seed yield and yield related traits in ethiopian mustard (Brassica carinata A. BRAUN). MSc. Thesis, Prsented to the School of Graduate studies, Haramaya University, Haramaya, Ethiopia. Link: https://bit.ly/2yQNZYR

53. Vivek BS, Krivanek AF, Palacios-Rojas N, Twumasi-Afriyie S, Diallo AO (2008) Breeding Quality Protein Maize (QPM): Protocols for Developing QPM Cultivars. Mexico, D.F. CIMMYT. Link: https://bit.ly/2Snctjj
Discover a bigger Impact and Visibility of your article publication with Peertechz Publications 